OPEN ACCESS

Edited by:

Richard Inger,

University of Exeter, UK

Reviewed by:

Donald Lundahl Phillips, U.S. Environmental Protection

Agency, USA

Seth Newsome,

University of New Mexico, USA

*Correspondence: Hannah B. Vander Zanden h.vanderzanden@utah.edu

Specialty section:

This article was submitted to

Population Dynamics,

a section of the journal

Frontiers in Ecology and Evolution

Received: 11 November 2015

Accepted: 24 February 2016

Published: 16 March 2016

Citation:

Vander Zanden $H B$, Soto DX, Bowen GJ and Hobson KA (2016) Expanding the Isotopic Toolbox: Applications of Hydrogen and Oxygen Stable Isotope Ratios to Food Web Studies. Front. Ecol. Evol. 4:20 doi: 10.3389/fevo.2016.00020

\section{Expanding the Isotopic Toolbox: Applications of Hydrogen and Oxygen Stable Isotope Ratios to Food Web Studies}

\author{
Hannah B. Vander Zanden ${ }^{*}$, David X. Soto ${ }^{2}$, Gabriel J. Bowen ${ }^{1}$ and Keith A. Hobson ${ }^{2,3}$ \\ ${ }^{1}$ Department of Geology and Geophysics, University of Utah, Salt Lake City, UT, USA, ${ }^{2}$ Environment Canada, Saskatoon, \\ Canada, ${ }^{3}$ Department of Biology, University of Western Ontario, London, ON, Canada
}

The measurement of stable carbon $\left(\delta^{13} \mathrm{C}\right)$ and nitrogen $\left(\delta^{15} \mathrm{~N}\right)$ isotopes in tissues of organisms has formed the foundation of isotopic food web reconstructions, as these values directly reflect assimilated diet. In contrast, stable hydrogen $\left(\delta^{2} H\right)$ and oxygen $\left(\delta^{18} \mathrm{O}\right)$ isotope measurements have typically been reserved for studies of migratory origin and paleoclimate reconstruction based on systematic relationships between organismal tissue and local environmental water. Recently, innovative applications using $\delta^{2} \mathrm{H}$ and, to a lesser extent, $\delta^{18} \mathrm{O}$ values have demonstrated potential for these elements to provide novel insights in modern food web studies. We explore the advantages and challenges associated with three applications of $\delta^{2} \mathrm{H}$ and $\delta^{18} \mathrm{O}$ values in food web studies. First, large $\delta^{2} \mathrm{H}$ differences between aquatic and terrestrial ecosystem end members can permit the quantification of energy inputs and nutrient fluxes between these two sources, with potential applications for determining allochthonous vs. autochthonous nutrient sources in freshwater systems and relative aquatic habitat utilization by terrestrial organisms. Next, some studies have identified a relationship between $\delta^{2} \mathrm{H}$ values and trophic position, which suggests that this marker may serve as a trophic indicator, in addition to the more commonly used $\delta^{15} \mathrm{~N}$ values. Finally, coupled measurements of $\delta^{2} \mathrm{H}$ and $\delta^{18} \mathrm{O}$ values are increasing as a result of reduced analytical challenges to measure both simultaneously and may provide additional ecological information over single element measurements. In some organisms, the isotopic ratios of these two elements are tightly coupled, whereas the isotopic disequilibrium in other organisms may offer insight into the diet and physiology of individuals. Although a coherent framework for interpreting $\delta^{2} \mathrm{H}$ and $\delta^{18} \mathrm{O}$ data in the context of food web studies is emerging, many fundamental uncertainties remain. We highlight directions for targeted research that will increase our understanding of how these markers move through food webs and reflect ecological processes.

Keywords: 18-oxygen, deuterium, diet, drinking water, isotopic discrimination, nutrient transfer, physiology, trophic position 


\section{INTRODUCTION}

The application of stable isotope measurements of both the organic and inorganic components of food webs has had a long and impressive history, and such measurements are now an indispensable tool for elucidating food web structure, nutrient and contaminant flows, and the foraging ecology of individuals and populations (Peterson and Fry, 1987; Rundel et al., 1989; Lajtha and Michener, 1994; Fry, 2006; Michener and Lajtha, 2007; Martínez del Rio et al., 2009; Boecklen et al., 2011). With massive environmental perturbations that characterize the current (Anthropocene) era, there will be a commensurate increase in the use and need for refinement of isotopic tools to investigate pressing environmental issues (Dawson and Seigwolf, 2007). This field has relied almost exclusively on the stable isotopes of relatively few elements, with the overwhelming contributions coming from the use of $\delta^{13} \mathrm{C}$ and $\delta^{15} \mathrm{~N}$ measurements and to a lesser extent those of $\delta^{34} \mathrm{~S}$ (Krouse and Grineko, 1971). This focus on C, N, and S derives from the fact that these elements are major components of animal and plant tissues that are sourced nearly exclusively from diet, thus their stable isotopes are ideal indicators of sources of primary production (e.g., $\left.\delta^{13} \mathrm{C}, \delta^{34} \mathrm{~S}\right)$ or trophic position $\left(\delta^{15} \mathrm{~N}\right)$. The use of isotopic bi-plots involving these elements to infer source of feeding, trophic position, and isotopic niche space is now routine in several disciplines (Post, 2002; Bearhop et al., 2004; Layman et al., 2007, 2012; Newsome et al., 2007, 2012; Jackson et al., 2011; Ofukany et al., 2014).

In contrast, even though water is essential to life on earth, measurements of the stable isotopes of $\mathrm{H}$ and $\mathrm{O}$, have rarely been used in modern animal trophic ecology. Instead, until recently, these isotopes were largely used to study the hydrological cycle by tracing water origins or reconstructing past climates (Clark and Fritz, 1997). That focus derived from the fact that the isotopic behavior of $\mathrm{H}$ and $\mathrm{O}$ in water is relatively well understood, and $\delta^{2} \mathrm{H}$ and $\delta^{18} \mathrm{O}$ values in water can provide key information on water origins (e.g., local precipitation, ground water), climate (ambient temperatures during condensation and precipitation) and the degree of evapotranspiration (Clark and Fritz, 1997).

Applications of $\delta^{2} \mathrm{H}$ measurements, and to a lesser extent $\delta^{18} \mathrm{O}$ measurements, in studies involving animals has increased tremendously through the linkage of spatial patterns in amountweighted precipitation $\delta^{2} \mathrm{H}$ and $\delta^{18} \mathrm{O}$ values (i.e., isoscapes) with those in animal tissues, especially metabolically inert tissues such as keratins (e.g., feathers, hair, claws) and chitins (e.g., insect wings) (Hobson and Wassenaar, 2008). Such linkage has made it possible to track movements and origins of a broad range of migratory animals, and also provides the foundation for forensic approaches to tracing origins of various animal- and plantbased materials (Bowen et al., 2005b; Meier-Augenstein, 2011). Because tissue $\mathrm{H}$ and $\mathrm{O}$ isotopic composition is influenced by diet in addition to environmental water, the application of these isotopes can also be used as a tracer of organismal food and resource use.

Although there has been a rich history of using water isotopes in investigations of plant physiology and water-use mechanisms, the relative paucity of studies using $\delta^{2} \mathrm{H}$ and $\delta^{18} \mathrm{O}$ values to examine diet and trophic processes is related in part to past difficulties in routine analyses of these isotopes in organic materials. Hydrogen forms weak bonds with $\mathrm{O}$ and $\mathrm{N}$ and will exchange with $\mathrm{H}$ in ambient waters both in vivo and in the laboratory. This has led to a number of challenges in deriving $\delta^{2} \mathrm{H}$ values for the non-exchangeable fraction of $\mathrm{H}$ in organic materials and the reporting of data (Wassenaar and Hobson, 2003, 2006; Meier-Augenstein et al., 2013). Both $\delta^{2} \mathrm{H}$ and $\delta^{18} \mathrm{O}$ analyses involve the use of pyrolytic combustion techniques and, for $\delta^{18} \mathrm{O}$, the need to separate the $\mathrm{N}_{2}$ and $\mathrm{CO}$ (i.e., mass 28) peaks for mass spectrometric analysis (Qi et al., 2011). While these challenges can be addressed, it is noteworthy that there are still no accepted organic international standards for $\delta^{2} \mathrm{H}$ and $\delta^{18} \mathrm{O}$ measurements (but see Coplen and Qi, 2012; Wassenaar et al., 2015), and many laboratories that routinely run organic materials for $\delta^{13} \mathrm{C}, \delta^{15} \mathrm{~N}$, and $\delta^{34} \mathrm{~S}$ measurements are unfamiliar with or not equipped to routinely run organic $\delta^{2} \mathrm{H}$ and $\delta^{18} \mathrm{O}$ measurements (Wassenaar et al., 2015). More fundamentally, there are aspects of animal metabolism involving $\mathrm{H}$ and $\mathrm{O}$ that present key challenges in understanding metabolic routing and the nature of isotopic discrimination within animals and between trophic levels, which are introduced in the following section and discussed throughout this review.

Our paper introduces the concept of using $\delta^{2} \mathrm{H}$ and $\delta^{18} \mathrm{O}$ measurements as a natural and valuable addition to the more familiar $\mathrm{C}, \mathrm{N}$, and $\mathrm{S}$ isotopic toolbox for delineating nutrient linkages, animal diets, and trophic relationships. We emphasize key differences in isotopic behavior of these isotopes especially related to the transition from well-understood inorganic phase to the much more complex stages involving animal physiology. We consider both aquatic and terrestrial systems and focus on key mechanisms related to isotopic routing and discrimination. Finally, we emphasize key research protocols and provide recommendations for future research. Our ultimate goal is to provide the reader with the necessary foundation and impetus to consider the use of the $\mathrm{H}$ and $\mathrm{O}$ isotopes more effectively in food web studies.

\section{INFLUENCES ON ANIMAL TISSUE $\delta^{2} \mathrm{H}$ AND $\delta^{18} O$ VALUES}

The primary challenges, as well as many of the opportunities, associated with the use of $\mathrm{H}$ and $\mathrm{O}$ as tracers within food webs stem from the fact that these isotopic systems integrate information on both diet and water balance. Metabolism and biosynthesis take place within the aqueous environments of the body, and most of the associated reactions involve potential for exchange of $\mathrm{H}$ and $\mathrm{O}$ between organic molecules and a consumer's body water. Thus, in contrast to $\mathrm{C}$ and $\mathrm{N}$, where atoms fixed in newly grown tissues can be considered to be derived solely from dietary items, $\mathrm{H}$ and $\mathrm{O}$ fixed in these same tissues may be a mixture of atoms derived from diet and body water (DeNiro and Epstein, 1981a; Hobson et al., 1999a; Ehleringer et al., 2008). Interpretation of $\mathrm{H}$ and $\mathrm{O}$ in the context of dietary ecology shares many of the same complications affecting $\mathrm{C}$ and $\mathrm{N}$ isotope data (e.g., diet-tissue 
routing, metabolic fractionation), but with $\mathrm{H}$ and $\mathrm{O}$ isotope ratios several additional complexities such as the isotopic mass balance of body water and water-tissue fractionation during biosynthesis are involved. The spectrum of potential controls on $\mathrm{H}$ and $\mathrm{O}$ isotope ratios measured for consumer tissues is now fairly clearly defined (Figure 1), although our knowledge of these controls varies, and as highlighted later in this review, major research opportunities remain to further elaborate and constrain the importance of many of these controls. Here we introduce the processes influencing $\delta^{2} \mathrm{H}$ and $\delta^{18} \mathrm{O}$ integration from environmental and dietary sources into organismal tissue following the conceptual diagram in Figure 1.

Any isotopic study of dietary ecology requires substantial, well-characterized variation in the isotopic composition of food items, but potential food sources are rarely analyzed for $\delta^{2} \mathrm{H}$ and $\delta^{18} \mathrm{O}$ values (but see Wolf and Martínez del Rio, 2000) except in the case of aquatic food web studies (see Energy Flow Pathways section). Variation in $\delta^{2} \mathrm{H}$ and $\delta^{18} \mathrm{O}$ values of dietary items stems mainly from hydrologic isotopic effects and biophysical processes occurring at lower trophic levels. Perhaps the best-studied hydrologic effect in this context is the largescale variation in environmental water isotope ratios resulting from the distillation of moisture from circulating air masses. This process produces substantial gradients in water isotope ratios that label local food webs and have great utility in migration ecology research, but the variation imparted is usually expressed over spatial scales much larger than the local foraging area of consumers and therefore of little direct relevance to dietary studies. Generally more relevant to food web studies is variation arising from local and regional hydrological processes, such as the aggregation of runoff in groundwater, streams, and lakes and evaporation from soils and surface water bodies (Bowen et al., 2011; Evaristo et al., 2015), or due to physiological processes such as isotopic enrichment associated with transpiration from land plants (Yakir and Deniro, 1990; Roden and Ehleringer, 1999; Marshall et al., 2007). For food webs where dietary items inherit their $\mathrm{H}$ and $\mathrm{O}$ from different hydrological pools or from plants characterized by different degrees of transpiratory enrichment, this may provide an isotopic "label" that can be traced from dietary items to consumer tissues (Wolf et al., 2002).

Perhaps the most challenging characteristic of the $\mathrm{H}$ and $\mathrm{O}$ isotopic systems for food web applications is that the isotopic composition of consumer tissues does not reflect dietary isotopic composition alone, but a blend of dietary and body water isotopic compositions. Understanding controls on the isotopic composition of water in vivo (within consumers) is thus critical for the accurate prediction of diet-tissue $\mathrm{H}$ and $\mathrm{O}$ isotope offsets. Models of the isotopic mass balance of bulk body water are fairly well developed as an outgrowth of work on human metabolism (Gretebeck et al., 1997; Schoeller, 1999; Podlesak et al., 2012) and ecological studies focusing on the O isotope ratios of tooth enamel and bone (Luz et al., 1984, 1990; Luz and Kolodny, 1985; Tatner, 1988; Ayliffe and Chivas, 1990; Bryant and Froelich, 1995; Kohn, 1996). These models require accurate information on the relative rates of input and output fluxes of water, including drinking, metabolic water production, intake of liquid water in food, and fractionating losses in breath and via transcutaneous water loss, which are known to vary among taxa and among individuals (Karasov and Martínez del Rio, 2007; Reynard and Hedges, 2008; O’Grady et al., 2010; Pecquerie et al., 2010). Perhaps more challenging,

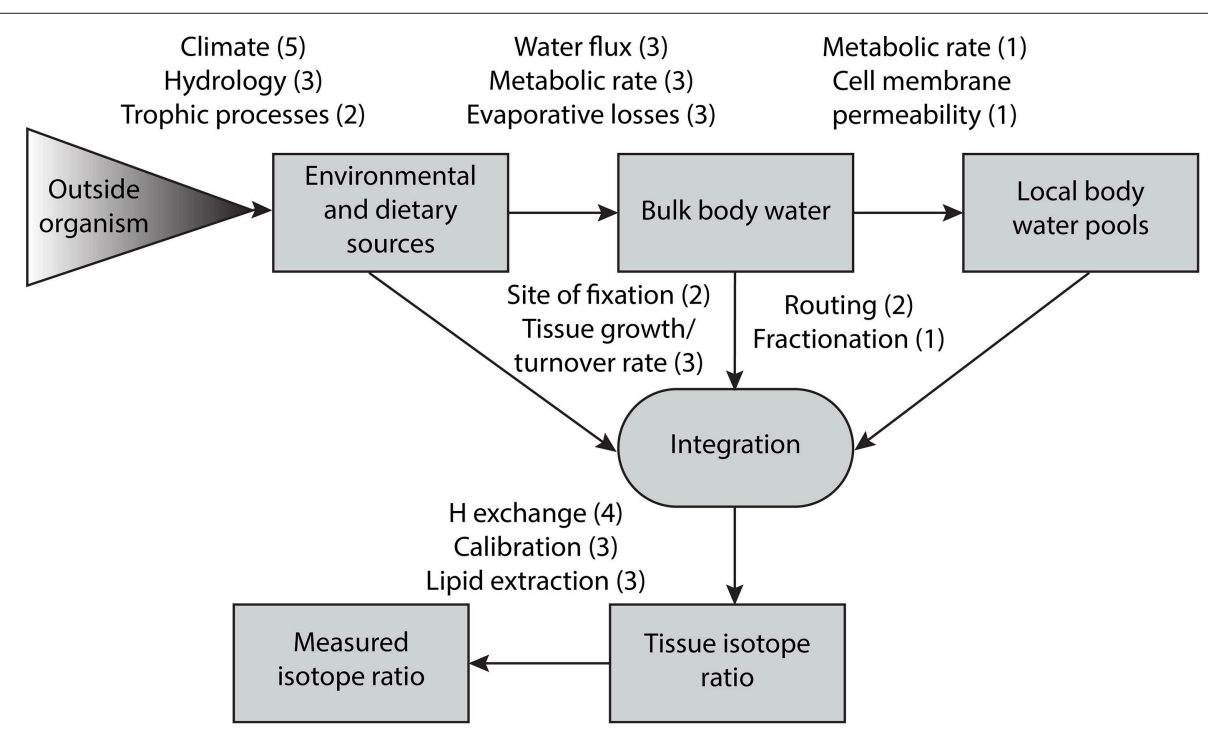

FIGURE 1 | This conceptual diagram summarizes the processes that influence $\delta^{2} \mathrm{H}$ and $\delta^{18} \mathrm{O}$ integration from environmental (water and molecular $\mathrm{O}_{2}$ ) and dietary sources into animal tissues. Boxed text indicates stages of integration and analytical measurement, whereas unboxed text indicates factors that can affect $\delta^{2} \mathrm{H}$ and $\delta^{18} \mathrm{O}$ values between these stages. The shaded triangle refers to processes that affect environmental and dietary sources prior to entering the organism. The number in parentheses after each factor indicates a level of understanding ranging from 1 (minimal understanding) to 5 (well-characterized). The four factors related to integration (site of fixation, tissue growth/turnover rate, routing, and fractionation) are relevant to all incoming sources (environmental and dietary sources, bulk body water, and local body water pools). 
significant differences have been demonstrated between the isotopic composition of inter- and intra-cellular water, most likely because rates of metabolic water production within some cells may exceed the rates of isotopic equilibration across cell membranes (Kreuzer-Martin et al., 2005). This means that the $\mathrm{H}$ and $\mathrm{O}$ isotopic composition of consumer body water may in fact be a heterogeneous mosaic of local body water pools, such that the physical location and conditions under which synthesis of a given tissue occurs may significantly affect the isotopic composition of the $\mathrm{H}$ and $\mathrm{O}$ atoms fixed to the newly assembled tissue.

Understanding the integration of dietary and physiological signals in the $\mathrm{H}$ and $\mathrm{O}$ isotopic composition of consumer tissues, as is also the case for $\mathrm{C}$ and $\mathrm{N}$, requires understanding of tissue growth and turnover rates, routing from water vs. food items to consumer tissues, and fractionation associated with synthesis reactions. Particularly for organisms that undergo a natural shift in the isotopic composition of $\mathrm{H}$ and $\mathrm{O}$ inputs due to a dietary shift or migration, understanding the timing of tissue synthesis in relation to the point at which isotopic equilibrium is reached is also important. Nevertheless, these shifts can provide an opportunity to examine ecological strategies of resource use (Wunder et al., 2012). Little work has addressed turnover with respect to $\mathrm{H}$ and $\mathrm{O}$ isotope ratios specifically, and tissue-specific times derived from other systems may or may not apply (O'Brien and Wooller, 2007; Podlesak et al., 2008; Storm-Suke et al., 2012).

Routing is of particular importance for the interpretation of $\mathrm{H}$ and $\mathrm{O}$ isotope data, and can be considered at two levels: molecular and atomic routing. As for $\mathrm{C}$ and $\mathrm{N}$, routing of molecules directly from dietary items will have a significant impact on bulk tissue-diet isotopic $\mathrm{H}$ and $\mathrm{O}$ offsets, particularly for $\mathrm{H}$, as the $\delta^{2} \mathrm{H}$ value of lipids is much lower than that of other macromolecules (Sessions et al., 1999; Sachse et al., 2012). Issues associated with molecular routing can largely be addressed by attempting to match substrates measured to characterize dietary item and consumer tissue values (e.g., through the removal of lipids from all samples where a protein substrate is measured from the consumer), but the efficacy of this approach may vary among applications and is not universally accepted (see Where to Go From Here section). For $\mathrm{H}$ and $\mathrm{O}$ isotopes, because of the potential for exchange between diet-derived macromolecules and body water, the fraction of atoms on these molecules that are routed directly from diet to consumer tissue must also be considered. This atomic routing sets the fraction of atoms in consumer tissue that carry a direct reflection of diet composition vs. those that are fixed from body water and thus carry a "mixed" signal of diet, environmental water composition, and body water balance. A large fraction of $\mathrm{H}$ atoms are bonded directly to the $\mathrm{C}$ skeleton of most biomolecules, whereas most $\mathrm{O}$ is found within functional groups, and theoretical assessments and experimental data suggest that atomic routing from diet to consumer tissues is in general much stronger for $\mathrm{H}$ than for $\mathrm{O}$ (Ehleringer et al., 2008; Bowen et al., 2009; Wang et al., 2009; Nielson and Bowen, 2010; Wolf et al., 2011; Soto et al., 2013c). This means that in most cases the expectation will be that $\mathrm{H}$ isotopes will carry a "purer" dietary signature and $\mathrm{O}$ will bear a stronger reflection of consumer physiological water balance. For $\mathrm{H}$ and $\mathrm{O}$ atoms that are not routed, but are fixed to substrate molecules in vivo, we can expect some fractionation between the body water pool and the fixed $\mathrm{H}$ and $\mathrm{O}$. Direct measurements of these fractionation factors do not exist, and whole-organism experiments conducted thus far involve too many free variables to derive the value of fractionation factors associated with biosynthesis.

This framework provides a basis for evaluating, further developing, and applying knowledge of the processes underlying the application of $\mathrm{H}$ and $\mathrm{O}$ to dietary ecology research, as elaborated throughout the rest of this review. In many cases our understanding of these factors is limited to indirect inferences drawn from field studies or constraints from a small number of experiments. Although a growing number of successful case studies suggest potential to apply $\mathrm{H}$ and $\mathrm{O}$ productively in food web studies, and in many cases a comprehensive processlevel understanding of $\mathrm{H}$ and $\mathrm{O}$ systematics in food webs may not be essential, most limitations and uncertainties associated with these applications can be evaluated within the context of the framework proposed here. In this sense, Figure 1 offers a template for evaluating the power of $\mathrm{H}$ and $\mathrm{O}$ isotopes to contribute to food web studies as well as a roadmap for future research that may further advance this power.

\section{ENERGY FLOW PATHWAYS}

\section{A New Tracer of Energy Flow in Aquatic Systems}

Spatially separated ecosystems may often be connected through energy and nutrient subsidies that are transported through biotic or physical vectors. Such allochthonous subsidies in the form of nutrients, detritus, prey, or consumers, can greatly influence the primary productivity of the recipient habitats (Polis et al., 1997). Connectivity between origin and destination can range widely among and between water and land habitats, and isotopic markers of $\mathrm{C}$ and $\mathrm{N}$ have been central to many studies in detecting and measuring these cross-ecosystem fluxes (Polis and Hurd, 1996; Kitchell et al., 1999; Stapp et al., 1999; Helfield and Naiman, 2001; Schindler and Lubetkin, 2004; Crait and BenDavid, 2007; Vander Zanden et al., 2012). More recently, H stable isotopes have been featured in a surge of research to trace energy flow pathways, principally in aquatic systems.

Land-to-water nutrient transport is common in food webs of streams, rivers, and lakes and these aquatic food webs are often supported both by primary productivity (autochthonous) and terrestrial (allochthonous) inputs (Figure 2, Polis et al., 1997). Distinguishing and quantifying these inputs originating from within the aquatic system vs. the surrounding landscape is important for understanding the functioning of food webs as well as their response to environmental change. Prior to the use of $\delta^{2} \mathrm{H}$ values, $\mathrm{C}$ stable isotopes were principally used as a marker for these studies. In some locales, $\delta^{13} \mathrm{C}$ values differ sufficiently between terrestrial and aquatic end members to distinguish these energy inputs (Rosenfeld and Roff, 1992; Junger and Planas, 1994; Doucett et al., 1996; Grey et al., 2001; Dekar et al., 2011), but there is not sufficient resolution in $\delta^{13} \mathrm{C}$ values for doing so in other cases (France, 1995; Finlay et al., 1999, 2002, 2010; Finlay, 


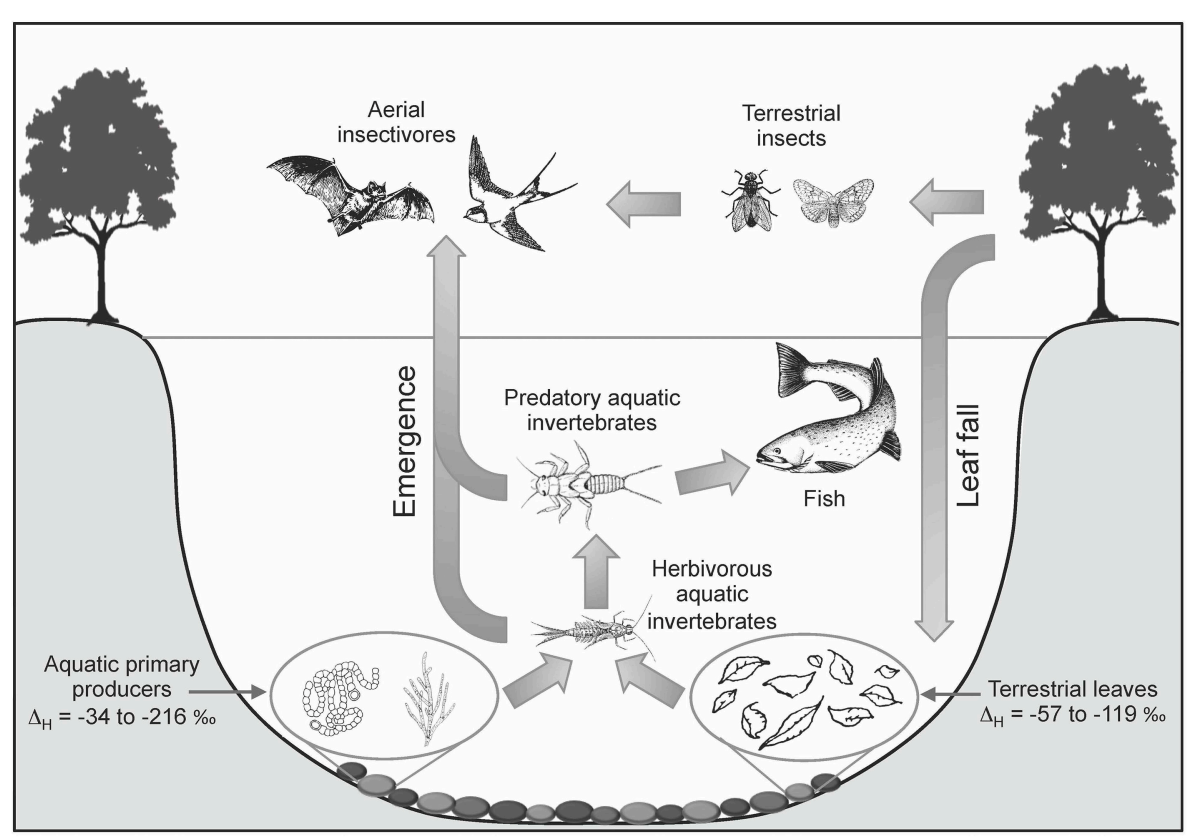

FIGURE 2 | Hydrogen isotope values are a useful tracer of land-to-water and water-to-land nutrient flow as a result in $\delta^{2} \mathrm{H}$ value differences between aquatic and terrestrial primary producers. The offset between $\delta^{2} \mathrm{H}_{\text {water }}$ and $\delta^{2} \mathrm{H}_{\text {producer }}\left(\Delta_{\mathrm{H}}\right.$, Equation 1$)$ is typically larger for aquatic primary producers (excluding macrophytes) than for terrestrial vegetation. The range for aquatic primary producers include phytoplankton, macroalgae, and benthic microalgae in rivers, lakes, and coastal systems, while the terrestrial vegetation range includes both deciduous and evergreen species (compiled by Hondula et al., 2014). These isotopic profiles can be measured in organisms within the aquatic food web to determine the autochthonous vs. allochthonous nutrient inputs. Additionally, emergent aquatic insects may also provide important nutrient subsidies to the terrestrial ecosystem that can be detected in the $\delta^{2} \mathrm{H}$ values of insectivorous organisms. Figure adapted from Baxter et al. (2005).

2001, 2004; Trudeau and Rasmussen, 2003; Singer et al., 2005; Hill and Middleton, 2006; Finlay and Kendall, 2007; Wilkinson et al., 2013b).

Doucett et al. (2007) first demonstrated that substantially divergent $\delta^{2} \mathrm{H}$ values in aquatic and terrestrial primary producers could be used to distinguish these two major inputs into freshwater systems and in turn, the relative proportions of nutrient input into higher trophic level organisms, such as benthic invertebrates and fish. While the $\mathrm{H}$ isotope approach has been repeatable in multiple aquatic ecosystems, characterizing and predicting this offset depends on understanding the influences on $\delta^{2} \mathrm{H}$ values in these primary producers (Figure 2). Autotrophs incorporate hydrogen from environmental water into their tissues, and aquatic primary producers typically have bulk biomass $\delta^{2} \mathrm{H}$ values that are $100-180 \%$ more negative than the source water due to fractionation during photosynthesis (Estep and Hoering, 1980; Yakir and Deniro, 1990). In contrast, terrestrial plants that photosynthesize in air undergo this same fractionation (Estep and Hoering, 1980), but transpiration causes enrichment of ${ }^{2} \mathrm{H}$ in leaf water, as deuterium is preferentially retained over protium during evaporation (Walker and Brunel, 1990; Roden and Ehleringer, 1999). Therefore, land plant tissue $\delta^{2} \mathrm{H}$ values may be only $80-90 \%$ lower than source water (Sternberg et al., 1984; Hondula et al., 2014). This isotopic discrimination $\left(\Delta_{\mathrm{H}}\right)$ can be calculated as the difference between the $\mathrm{H}$ stable isotope ratios of producer organic matter and water (sensu Hondula et al., 2014):

$$
\Delta_{\mathrm{H}}=\left(\delta^{2} \mathrm{H}_{\mathrm{om}}-\delta^{2} \mathrm{H}_{\mathrm{water}}\right) /\left(1+\left(\delta^{2} \mathrm{H}_{\mathrm{water}} / 1000\right)\right)
$$

A comprehensive field survey spanning river, lake, and coastal lagoon habitats revealed that three major categories of aquatic primary producers (phytoplankton, macroalgae, and benthic microalgae) were significantly different from terrestrial vegetation in all of the different habitats studied (Hondula et al., 2014). However, terrestrial vegetation cannot always be distinguished from vascular aquatic plants with $\delta^{2} \mathrm{H}$ values (Evans, 2012; Hondula et al., 2014). The mechanisms for the isotopic similarity between vascular aquatic and terrestrial plants have not been identified, but it is possible that variation in ${ }^{2} \mathrm{H}$ enrichment via transpiration is not the sole explanation for differences in $\delta^{2} \mathrm{H}$ values between terrestrial and aquatic autotrophs (Hondula et al., 2014). Without further understanding of the drivers for $\delta^{2} \mathrm{H}$ composition of aquatic macrophytes, the use of hydrogen isotopes in lakes or rivers where macrophytes can be a significant part of the food web may result in a limited ability to distinguish allochthonous vs. autochothonus nutrient inputs. Nevertheless, the substantial and systematic difference in hydrogen isotope discrimination among of non-macrophyte aquatic and terrestrial primary producers across freshwater and marine ecosystems can aid 
in discriminating organic matter sources and identify nutrient subsidies (Hondula et al., 2014).

\section{Applications to Determine Resource Use across Organisms and Ecosystems}

In tracing food web processes with $\delta^{2} \mathrm{H}$ values, the most common applications have been to quantify land-to-water energy flows in streams, rivers, lakes, and even coastal lagoons, but $\delta^{2} \mathrm{H}$ values have also been used to trace the reverse process: water-to-land energy flow (Myers et al., 2012; Stenroth et al., 2015; Voigt et al., 2015). We also explore some of the other unique applications of $\mathrm{H}$ isotopes in food webs, which include determining the resources that support aquacultured and invasive species (Cole and Solomon, 2012; Evans, 2012; Foley et al., 2014; Hondula and Pace, 2014; Emery et al., in press), how stream food webs respond to fire (Cooper et al., 2015), interactions between hydrology and turbidity in river ecosystems (Roach and Winemiller, 2015), and detecting contributions of methanotrophic biomass (Deines et al., 2009).

The structure of land-to-water resource subsidy and consumption is not equal among aquatic ecosystems, and resources are not always consumed in proportion to their abundance or loading rates (Batt et al., 2012; Cole and Solomon, 2012; Karlsson et al., 2012). Thus, measurements of $\delta^{2} \mathrm{H}$ values have offered an important tool for quantifying this subsidy. Whereas land-to-water subsidies have been well recognized for benthic organisms in streams, rivers, and lakes, terrestrial subsidies to pelagic consumers in lakes were typically more difficult to demonstrate. An isotopic approach including $\delta^{2} \mathrm{H}$ values suggested that the significant terrestrial support of pelagic consumers is widespread (Cole et al., 2011; Wilkinson et al., 2013a). Allochthony is a common feature among these ecosystems, but it is extremely variable across water bodies, time, and space, ranging from undetectable to dominant (Berggren et al., 2014, 2015). Some of this variability may be due to morphological, biological, and chemical properties among water bodies, as well as differences in methodology among studies (Wilkinson et al., 2013a; Berggren et al., 2014; Collins et al., in press). In streams where riparian vegetation has burned due to wildfire, the autochthonous contribution dominates stream food webs (Cooper et al., 2015). This is likely a result of shading effects, as stream allochthonous energy use is correlated with canopy cover (Collins et al., in press). Streamflow regime has been found to influence the degree of allochthony in rivers, with algae dominating nutrient contributions to macroinvertebrates and fish following low flow periods, while terrestrial plants made higher contributions following high-flow pulses (Roach and Winemiller, 2015). In reservoir ecosystems, the importance of the allochthonous subsidy is variable, but is negatively correlated with watershed size (Babler et al., 2011) and negatively correlated with reservoir age (Emery et al., 2015). The existing literature supports the hypothesis that percentage of terrestrial organic matter in zooplankton should be highest in humic lakes with low phytoplankton biomass, and lowest in either eutrophic lakes, or clear-water lakes (Berggren et al., 2014), but further work is needed to model and predict this variation among ecosystems (Cole et al., 2011).

Understanding how different consumers use the available resources is also important. In aquacultured bivalves, it can be difficult to identify the sources of organic matter supporting the diet, as field-raised bivalves use in situ food sources and may experience fluctuating environmental conditions (Hondula and Pace, 2014). Oysters and clams raised within aquaculture settings can have spatially variable diets and have been shown to utilize macroalgae, which was previously thought to rarely provide the dominant energy source for bivalves (Hondula and Pace, 2014; Emery et al., in press). In other cases, the consumers of interest have been invasive species, and $\mathrm{H}$ isotopes have been useful in elucidating resource use of these organisms as well. The biomass of invasive zebra mussels (Dreissena polymorpha) in the Hudson River food web is greater than all other consumers combined (Cole and Solomon, 2012). In an ecosystem where organic matter pools are heavily dominated by terrestrial detritus (60-80\%), the zebra mussels do not use the terrestrial resources in proportion to their availability ( $\sim 40 \%$ allochthony), and selectively feed on autochthonous material (Cole and Solomon, 2012). Similarly, both zebra mussels and another invasive species, the quagga mussel (Dreissena rostriformis bugensis) in the Great Lakes, derived more of their food from autochothonous sources compared to the native mussel (Diporieia spp.) (Foley et al., 2014). Evans (2012) compared the percent autochthony vs. allochthony in native and invasive lamprey species from rivers in Michigan and Ohio, and found that terrestrial vegetation was more dominant in the diet of the native species in most cases. Thus, different consumers can rely on different basal resources, and $\delta^{2} \mathrm{H}$ values can be particularly helpful in determining the relative resource contributions to a given consumer.

In the reverse direction, an important component of the water-to-land linkage is the biomass from emergent aquatic insects. These insects subsidize terrestrial food webs along small streams by constituting an important part of the diet of many bats, birds, lizards, and spiders (Baxter et al., 2005; Richardson et al., 2010). The $\delta^{2} \mathrm{H}$ values of aquatic invertebrates do not change after emergence (because emergent aquatic insects typically do not feed as adults) and are sufficiently different from the $\delta^{2} \mathrm{H}$ values of terrestrial invertebrates to distinguish the habitat source with high accuracy (Myers et al., 2012; Stenroth et al., 2015). $\mathrm{H}$ isotopes have also been used to assess the ecological niche of bats and their relative association to aquatic or terrestrial habitats, and may offer insight into the variability in $\delta^{2} \mathrm{H}$ values of birds and bats not explained by $\delta^{2} \mathrm{H}$ values in local precipitation (Voigt et al., 2015). These water-to-land subsidies can be highly seasonal, with peak emergence in the early summer, and they can also exert indirect effects in the riparian habitat (Baxter et al., 2005). The degree of aquatic resource exploitation by terrestrial invertebrate consumers may also be influenced by land use along streams (e.g., percentage of agricultural use vs. natural forest) (Stenroth et al., 2015).

Stable isotopes have also been vital in tracing methane inputs into food webs (Grey, 2016). However, interpretation of C isotope data can be particularly problematic in freshwater food webs that receive methane $\left(\mathrm{CH}_{4}\right)$ subsidies. When comparing 
reliance on algal production vs. methanotropic bacterial biomass, variation in $\delta^{13} \mathrm{C}$ values can be too high (Grey and Deines, 2005), thus the addition of $\delta^{2} \mathrm{H}$ values to the study of methane-derived subsidies in freshwater food webs has also been advantageous. Not only can the combination of isotopes aid in distinguishing the linkages between microbial fauna in lake sediment and macroinvertebrate consumers, but it can also distinguish which of the two biochemical pathways was being used during $\mathrm{CH}_{4}$ formation by methanogens (Deines et al., 2009).

\section{Tools for Analysis}

In order to parse the relative contributions of allochthonous and autochthonous sources of productivity, it is necessary to use mixing models, which have increased in sophistication over the past decade (Phillips et al., 2014). These range from simple linear mixing models, such as IsoSource, that do not necessarily incorporate complexities such as variability in isotope values, hierarchical variance structure, and discrimination factors, to fully Bayesian mixing models that permit more flexibility and may incorporate some or all of these features. There are several off-the-shelf Bayesian models and packages available (see Phillips et al., 2014), but biologists in this field have mainly used SIAR (Dekar et al., 2011; Berggren et al., 2014; Hondula and Pace, 2014; Roach and Winemiller, 2015; Stenroth et al., 2015) and MixSIR (Evans, 2012). Note that SIAR development has halted and the new MixSIAR GUI (graphical user interface) provides a collaboration between SIAR and MixSIR, while the mixing model components of SIAR are still available as an $\mathrm{R}$ package called simmr. Both MixSIAR and simmr are available through GitHub.

Solomon et al. (2011) used a Bayesian mixing model to incorporate parameters specific to aquatic food web ecology, such as the per-trophic-level contribution of environmental water to consumer $\mathrm{H}$ (see $\delta^{2} H$ Values as a Trophic Indicator section), which has also been adapted for use in other aquatic food web studies (Batt et al., 2012, 2015; Cole and Solomon, 2012; Wilkinson et al., 2013a, 2015; Emery et al., 2015, in press). In a comparison of a linear mixing model (IsoSource) to a Bayesian mixing model, IsoSource overestimated the terrestrial contribution by about $10 \%$ compared to the Bayesian results and could not account for multiple sources of uncertainty, rendering the uncertainty around the mean estimates incomparable for the two approaches (Cole and Solomon, 2012). Therefore, a Bayesian approach, particularly one that can be adapted to the specific parameters relevant to aquatic food webs and uncertainty, is recommended.

Any of these mixing models may also incorporate $\mathrm{C}$ and/or $\mathrm{N}$ isotopes in addition to those of $\mathrm{H}$ (Jardine et al., 2009; Cole et al., 2011; Dekar et al., 2011; Solomon et al., 2011; Batt et al., 2012, 2015; Cole and Solomon, 2012; Evans, 2012; Wilkinson et al., 2013a; Berggren et al., 2014; Hondula and Pace, 2014; Stenroth et al., 2015; Voigt et al., 2015). Because the biogeochemical controls on each of the elements are different, in many cases it can be more powerful to use the multiple tracers together to resolve contributions of potential nutrient sources (Jardine et al., 2009; Cole et al., 2011; Soto et al., 2013a; Hondula and Pace, 2014).

\section{$\delta^{2} \mathrm{H}$ VALUES AS A TROPHIC INDICATOR}

\section{A New Trophic Tracer for Food Web Studies}

The trophic levels of a simple food chain with declining numbers of individuals at higher levels was the early vision for a food web that Charles Elton showed in his classical book for animal ecology (Elton, 1927). However, the use of discrete trophic levels can be too simplistic to evaluate trophic structure and dynamics because of complex interactions in ecological communities (Lindeman, 1942; Polis and Strong, 1996). Food webs are highly interconnected systems that present an intrinsic complexity with several original sources of energy such as photoautotrophs and chemoautotrophs. In addition, subsidies from spatially separated ecosystems (i.e., allochthonous inputs) can often be incorporated within the network of trophic connections (see Energy Flow Pathways section).

The use of $\delta^{13} \mathrm{C}$ and $\delta^{15} \mathrm{~N}$ measurements is often insufficient for unraveling complex food webs, especially in cases with little isotopic differentiation among primary sources (Fry, 2013; Soto et al., 2013a). Interest in using $\mathrm{H}$ isotopes to trace food web patterns comes from the pioneering work of Estep and Dabrowski (1980), which was published shortly before other work demonstrating the use of $\mathrm{N}$ isotopes as trophic tracer (DeNiro and Epstein, 1981b). In this early work, it was observed that the $\mathrm{H}$ isotopic composition of mouse tissue was highly correlated with the hydrogen isotopic content of the diet (Estep and Dabrowski, 1980). Surprisingly, despite these promising developments, little research involving $\mathrm{H}$ isotopes in food web studies was conducted until the 2000s. The primary reasons for slow progress were likely the presence of several confounding environmental factors and methodological issues during sample processing.

In contrast, the potential for the use of $\delta^{18} \mathrm{O}$ values in food web studies has been quite limited. The $\mathrm{O}$ isotope composition of animal tissues seems to be poorly related to that of dietary sources. Only $10 \%$ of the oxygen in chitin from aquatic crustaceans is derived from food (Nielson and Bowen, 2010), while the dietary contribution of $\mathrm{O}$ to human hair protein was estimated to be $\sim 8 \%$ (Ehleringer et al., 2008), although that study may have underestimated the atomic routing of $\mathrm{O}$ from diet to hair keratin. This implies that changes in $\delta^{18} \mathrm{O}$ values of environmental and body water are the main drivers of the tissue O isotopic composition variability (Ehleringer et al., 2008; Wang et al., 2009; Nielson and Bowen, 2010; Soto et al., 2013c; Schilder et al., 2015; but see cautions for feline carnioves, Pietsch et al., 2011), and that little trophic information is obtained by using $\delta^{18} \mathrm{O}$ values.

\section{Trophic Discrimination and $\delta^{2} \mathbf{H}$}

For $\delta{ }^{15} \mathrm{~N}$ values, kinetic fractionation effects occur in the enzyme-mediated biological reactions during the catabolism and excretion of proteins, thus resulting in an enrichment of ${ }^{15} \mathrm{~N}$ relative to diet, although the magnitude of the diet-tissue discrimination factor can be quite variable (Hobson and Clark, 1992; McCutchan et al., 2003; Vanderklift and Ponsard, 2003; Robbins et al., 2005; Caut et al., 2009; Hussey et al., 2014). For $\mathrm{H}$ isotopes, it is not clear whether the trophic enrichment 
observed in consumers relative to their diet is because of a trophic compounding effect related to accumulating environmental water contributions in food chains (see Trophic Compounding below; Solomon et al., 2009; Soto et al., 2013c) or due to metabolism as seen with $\delta^{15} \mathrm{~N}$ measurements. Some studies have found a weak correlation between $\delta^{2} \mathrm{H}$ and $\delta^{15} \mathrm{~N}$ values in food webs (Birchall et al., 2005; Soto et al., 2011; Topalov et al., 2013) suggesting the accumulation of exchange with ambient water $\mathrm{H}$ at each trophic level might be causing an apparent trophic enrichment in ${ }^{2} \mathrm{H}$ in some systems.

To date, there is little experimental support for metabolic fractionation as the mechanism for changes in $\delta^{2} \mathrm{H}$ values in terrestrial and aquatic organisms after accounting for other mechanisms such as the contribution of environmental water (Hobson et al., 1999a; Ehleringer et al., 2008; Solomon et al., 2009; Myers et al., 2012; Soto et al., 2013c). Nonetheless, data from bone collagen $\delta^{2} \mathrm{H}$ measurements appear to reflect trophic level, such that $\delta^{2} \mathrm{H}$ values of carnivores are higher relative to those of other omnivore/herbivore species (Birchall et al., 2005; Topalov et al., 2013). Birchall et al. (2005) reported that those differences were ca. $90 \%$ in a collection of 19 species of non-migratory mammals, birds, and fish from Great Britain, though it is important to note that that this study mixed aquatic and terrestrial organisms, and the methodology for the $\delta^{2} \mathrm{H}$ measurements did not account for exchangeable $\mathrm{H}$ in the collagen samples (which is problematic given the hygroscopic nature of the tissue). Another study involving $\mathrm{H}$ isotopes in a controlled laboratory plant-insect system also found a significant trophic enrichment between plant and moth tissues in larvae and adults (Peters et al., 2012), which contradicts the findings of a separate controlled study that observed a negligible diet-tissue discrimination between monarch butterflies and host milkweed (Hobson et al., 1999b). Whether this trophic enrichment described occurs broadly in terrestrial organisms, and whether it is caused by a similar mechanism such the apparent trophic compounding effect found in aquatic organisms, is still unknown. We thus recommend assessing the potential trophic use of $\delta^{2} \mathrm{H}$ values on a case-bycase basis and accounting for apparent trophic compounding, especially in aquatic systems, which we address in more detail below.

\section{Trophic Compounding}

Applying $\delta^{2} \mathrm{H}$ values as a food web tracer requires an understanding of how $\mathrm{H}$ isotopes are transferred trophically. Sources of $\mathrm{H}$ to consumer tissues include both diet and environmental water (Figure 1). Since environmental water generally has higher $\delta^{2} \mathrm{H}$ values than either aquatic or terrestrial primary producer biomass, and since the synthesis of new tissues at each trophic level involves fixation of $\mathrm{H}$ and $\mathrm{O}$ from environmental water, the effect of the blending of $\mathrm{H}$ from these two sources will be a progressive enrichment of the heavy isotopes at each trophic level (Figure 3). Solomon et al. (2009) first proposed accounting for the proportion of tissue $\mathrm{H}$ derived from environmental water $(\omega)$ because the consumer $\delta^{2} \mathrm{H}$ value $\left(\delta^{2} \mathrm{H}_{\text {consumer }}\right)$ alone is not enough to infer dietary sources $\left(\delta^{2} \mathrm{H}_{\text {diet }}\right)$ without taking into account this trophic compounding effect:

$$
\begin{aligned}
\delta^{2} \mathrm{H}_{\text {consumer }}= & \left(\omega_{\text {compound }} \times \delta^{2} \mathrm{H}_{\text {water }}\right) \\
& +\left(\left(1-\omega_{\text {compound }}\right) \times \delta^{2} \mathrm{H}_{\text {diet }}\right)
\end{aligned}
$$

where $\delta^{2} \mathrm{H}_{\text {water }}$ is the $\delta^{2} \mathrm{H}$ value of environmental water and $\omega_{\text {compound }}$ is the total contribution of environmental water in tissue $H$. The value of $\omega_{\text {compound }}$ can be calculated as:

$$
\omega_{\text {compound }}=1-(1-\omega)^{\tau}
$$

where $\tau$ is the difference in trophic level between the resource and the consumer. In Equation (3), the trophic position of the consumer relative to the resource baseline is needed to calculate the total contribution of environmental water to tissue $\mathrm{H}$, and this is commonly estimated by using $\mathrm{N}$ isotopes (Post, 2002). Additionally, the proportion of tissue $\mathrm{H}$ derived from ambient water $(\omega)$ in each trophic step, which can vary considerably (between 0 and 50\%; Solomon et al., 2009; Soto et al., 2013c; Wilkinson et al., 2015), needs to be determined or estimated. Using a mean value of $\omega=0.17, \omega_{\text {compound }}$ would approach 0.4 in high level consumers (Solomon et al., 2009). Indeed, a compilation of $\omega$ values from 24 consumers from both freshwater and marine habitats supports this upper threshold of 0.4 for $\omega_{\text {compound }}$ (Wilkinson et al., 2015). With more stringent criteria, $\omega_{\text {compound }}$ was estimated at 0.23 , and a reasonable assumed value of $\omega$ in the absence of other data was suggested to be 0.20 (Wilkinson et al., 2015). When a species- and systemspecific measurement is available for $\omega$, then it should be used preferentially. The use of some Bayesian mixing models can also incorporate uncertainty in the estimate of this parameter as well (Cole et al., 2011; Solomon et al., 2011; Roach and Winemiller, 2015; Emery et al., in press).

\section{COMBINED $\delta^{2} \mathrm{H}$ AND $\delta^{18}$ O VALUES}

\section{Paired Measurements of $\mathrm{H}$ and $\mathrm{O}$ Isotopes}

Most of the research cited thus far has used exclusively $\mathrm{H}$ isotopes, yet both the elements of $\mathrm{H}$ and $\mathrm{O}$ are strongly linked in environmental waters through the meteoric water relationship. More recent analytical techniques can permit the analysis of $\delta^{2} \mathrm{H}$ and $\delta^{18} \mathrm{O}$ values from the same pyrolysis (Qi et al., 2011; Meier-Augenstein et al., 2013), thus offering the possibility to infer greater information on the diet, climatic conditions, and the "water web" (sensu McCluney and Sabo, 2010) used by organisms. Measurements of $\delta^{18} \mathrm{O}$ values in organic tissues are scarce but increasing in frequency, as they had previously been limited mainly to measurements of inorganic tissues such as phosphates and carbonates of bone and tooth enamel, and $\delta^{18} \mathrm{O}$ data may complement that of $\delta^{13} \mathrm{C}$ and $\delta^{15} \mathrm{~N}$ in bone collagen in both modern and paleoecological contexts (Crowley et al., 2015). Interpreting $\mathrm{H}$ and $\mathrm{O}$ isotopic data also requires an understanding of what these measurements represent, such as the proportion of each element that is incorporated from diet vs. environmental water and how the observed relationship relates to the meteoric water line, as a number of studies have observed decoupling between $\delta^{2} \mathrm{H}$ and $\delta^{18} \mathrm{O}$ values in organisms and meteoric water. 


\section{Proportion Diet vs. Environmental Water}

As highlighted previously, the $\mathrm{C}$ and $\mathrm{N}$ in organismal tissues can be derived only from dietary sources, where $\mathrm{H}$ and $\mathrm{O}$ have multiple sources: diet, environmental or drinking water, and atmospheric $\mathrm{O}_{2}$ (the latter only applies to $\delta^{18} \mathrm{O}$ values). Theoretical models and experimental laboratory studies have focused on calculating the proportion of $\mathrm{H}$ and $\mathrm{O}$ derived from drinking (or environmental) water, mostly for purposes of geolocation, though the corresponding dietary information is also relevant for food web studies. The proportion of environmental water contributing to organismal tissue $\delta^{2} \mathrm{H}$ and $\delta^{18} \mathrm{O}$ values varies widely among organisms and tissues (Table $\mathbf{1}$ ). In general, environmental water contributions make up a small fraction of the tissue $\delta^{2} \mathrm{H}$ composition, ranging from $12 \%$ in fish muscle (Solomon et al., 2009) to 70\% in bird muscle (Wolf et al., 2012), with a larger proportion of tissue $\delta^{2} \mathrm{H}$ influence typically originating from diet. In contrast, tissue $\delta^{18} \mathrm{O}$ values appear to be more influenced by environmental water than diet contributions, though the range in proportional contribution of environmental waters to tissue $\delta^{18} \mathrm{O}$ values is also large, with as little as $15 \%$ in house sparrow red blood cells (Wolf et al., 2011) to $87 \%$ in chironomids originating from environmental water (Soto et al., 2013c).

\section{Decoupling in Tissue and Environmental Water}

Theoretical models derived for predicting the isotopic composition of human hair based on drinking water and dietary inputs explain $85 \%$ of the variability in observed variations of samples from the United States (Ehleringer et al., 2008) and have been validated in non-human primates (O'Grady et al., 2012). The observed slopes in the strong linear relationships between $\delta^{18} \mathrm{O}_{\text {tissue }}$ and $\delta^{2} \mathrm{H}_{\text {tissue }}$ are typically lower than the slope of $8\left(\delta^{2} \mathrm{H}=8 * \delta^{18} \mathrm{O}+10\right)$ in the meteoric water relationship (Craig, 1961), ranging from 5.0 to 8.3 in humans (Fraser et al., 2006; O'Brien and Wooller, 2007; Ehleringer et al., 2008; Bowen et al., 2009; Thompson et al., 2010); 6.4-7.2 in birds (Wolf et al., 2011); and 3.8-5.8 in insects (McCluney and Sabo, 2010). The shallower slope may be a result of differing and separate controls on $\delta^{2} \mathrm{H}_{\text {tissue }}$ and $\delta^{18} \mathrm{O}_{\text {tissue }}$ values, such as proportion local diet fraction and fraction of tissue $\mathrm{H}$ fixed in vivo (Bowen et al., 2009).

In particular, theoretical calculations and data from human hair samples suggests potential to use the coupled $\delta^{2} \mathrm{H} / \delta^{18} \mathrm{O}$ system as an indicator of situations where the isotope ratios of environmental water contributing to dietary items and directly to the consumer's body water (e.g., as drinking water or water in the life environment of aquatic organisms) are very different. Bowen et al. (2009) showed that hair samples collected from early-twentieth century Inuit living traditional lifestyles deviated dramatically from the covariant $\delta^{2} \mathrm{H} / \delta^{18} \mathrm{O}$ relationships seen in other humans (Figure 4). Modeling suggested that these distinctive values could be explained by the expected preferential atomic routing of $\mathrm{H}$ from ${ }^{2} \mathrm{H}$-enriched marine dietary items to keratin combined with the dominance of ${ }^{18} \mathrm{O}$-depleted drinking water on keratin ${ }^{18} \mathrm{O}$. This suggests that the dual-isotope system

TABLE 1 | Measured source contributions to organismal tissue $\delta^{2} \mathrm{H}$ and $\delta^{18} \mathrm{O}$ values.

\begin{tabular}{|c|c|c|c|c|c|c|c|}
\hline \multirow[t]{2}{*}{ Organism } & \multicolumn{2}{|l|}{$\delta^{2} \mathrm{H}$} & \multicolumn{3}{|c|}{$\delta^{18} \mathrm{O}$} & \multirow[t]{2}{*}{ Tissue } & \multirow[t]{2}{*}{ Source } \\
\hline & $\begin{array}{c}\text { Environmental } \\
\text { water (\%) }\end{array}$ & Diet (\%) & $\begin{array}{c}\text { Environmental } \\
\text { water (\%) }\end{array}$ & Diet (\%) & $\begin{array}{c}\text { Molecular } \\
\mathrm{O}_{2}(\%)\end{array}$ & & \\
\hline \multirow[t]{3}{*}{ Humans } & 31 & $69^{*}$ & - & - & - & Hair & Sharp et al., 2003 \\
\hline & 36 & $64^{\star}$ & 27 & & & Hair & O'Brien and Wooller, 2007 \\
\hline & 27 & $73^{*}$ & 35 & & & Hair & Ehleringer et al., 2008 \\
\hline \multirow[t]{2}{*}{ Rodents } & 71 & 29 & 56 & 15 & 30 & Body water & Podlesak et al., 2008 \\
\hline & 25 & $75^{*}$ & 45 & & & Hair & Podlesak et al., 2008 \\
\hline \multirow[t]{3}{*}{ Birds } & 18-32 & $68-82^{*}$ & - & - & - & Blood, muscle, liver, lipids, feather, nail & Hobson et al., 1999a \\
\hline & $14-18$ & $82-86^{*}$ & $15-27$ & & & Feathers, blood & Wolf et al., 2011 \\
\hline & $26-70^{\star}$ & $30-74$ & - & - & - & Plasma, red blood cells, intestine, muscle & Wolf et al., 2012 \\
\hline \multirow[t]{3}{*}{ Fish } & 12 & $88^{\star}$ & - & - & - & Muscle & Solomon et al., 2009 \\
\hline & 33 & $67^{*}$ & 84 & & & Lipid-free muscle & Soto et al., $2013 \mathrm{c}$ \\
\hline & $23-25$ & $75-77$ & - & - & - & Lipid-free muscle, liver & Newsome et al., in review \\
\hline \multirow[t]{3}{*}{ Insects } & $14-39$ & $61-86^{\star}$ & - & - & - & Whole organism & Solomon et al., 2009 \\
\hline & 30 & 70 & 70 & & & Whole organism & Wang et al., 2009 \\
\hline & 47 & $53^{*}$ & 87 & & & Lipid-free whole organism & Soto et al., 2013c \\
\hline \multirow[t]{2}{*}{ Crustaceans } & 38 & 29 & 69 & 10 & 21 & Chitin & Nielson and Bowen, 2010 \\
\hline & - & - & $56-69$ & & & Whole organism, eggs & Schilder et al., 2015 \\
\hline
\end{tabular}

When available, diet and molecular $\mathrm{O}_{2}$ proportions are also reported.

${ }^{\star}$ If only one source $\delta^{2} \mathrm{H}$ measurement was reported (environmental water vs. dietary contributions), the other was calculated as $100-X$. 


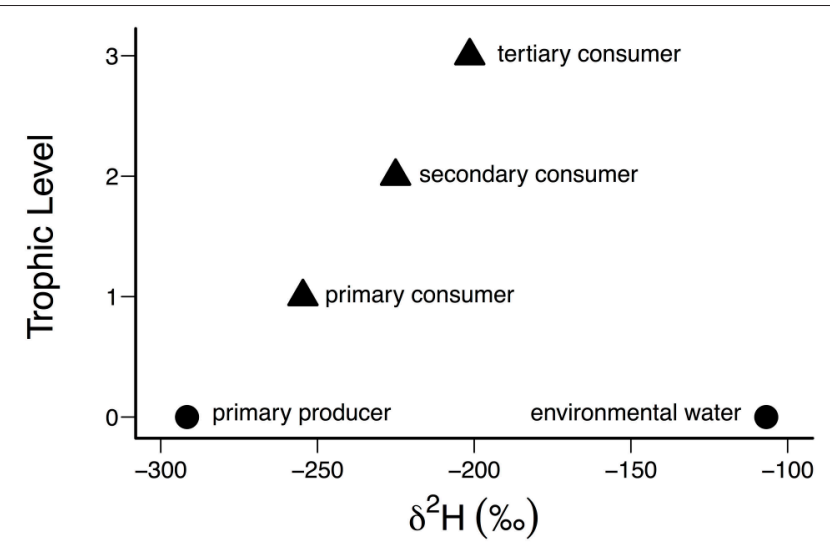

FIGURE 3 | Trophic compounding occurs in this food chain example consisting of three trophic levels. Each trophic level is assumed to consume from only the next lowest trophic level. The total contribution of environmental water to consumer tissue $\delta^{2} \mathrm{H}$ values depends on the value of $\omega_{\text {compound }}$ and its trophic level, such that increasing contributions of environmental water to consumer tissue at each trophic level cause an increase in $\delta^{2} \mathrm{H}$ values. The value of $\omega$ was assumed to be constant at 0.2 in this example, while $\omega_{\text {compound }}=1-(1-\omega)^{\tau}$, and $\tau$ represents the trophic level. Aquatic primary producer (-291.6\% , filamentous algae) and environmental water $(-106.8 \%$ o $) \delta^{2} \mathrm{H}$ values used in this example are real measurements from the Colorado River (Doucett et al., 2007). Values of $\delta^{2} \mathrm{H}$ were calculated using Equations (2) and (3) (see text).

could provide a powerful tracer, in particular, of consumption of marine foods by terrestrial consumers or terrestrial subsidies to marine food webs. Some indirect evidence for the latter may be found in the anomalous $\delta^{2} \mathrm{H} / \delta^{18} \mathrm{O}$ values observed for some commercially harvested marine bivalves (Chesson et al., 2011), but controlled tests of this idea and applications to natural systems have not yet emerged.

In contrast to the tight $\delta^{2} \mathrm{H}_{\text {tissue }} / \delta^{18} \mathrm{O}_{\text {tissue }}$ relationships observed in the majority of human and primate data, the literature also contains examples of altogether weak tissue/tissue (e.g., $\delta^{2} \mathrm{H}_{\text {tissue }} / \delta^{18} \mathrm{O}_{\text {tissue }}$ ) or tissue/source-water relationships (e.g., $\delta^{2} \mathrm{H}_{\text {tissue }} / \delta^{2} \mathrm{H}_{\text {water }}, \delta^{18} \mathrm{O}_{\text {tissue }} / \delta^{18} \mathrm{O}_{\text {water }}$ ) in other organisms, which suggest that we have more to learn about controls on these isotopic systems. A tissue/source-water disequilibrium in one of the two isotopes may suggest differences in the proportional contribution of diet and environmental water to the tissue isotope signal. Given that a greater proportion of $\mathrm{O}$ is derived from environmental water than for $\mathrm{H}$ in many organismal tissues (Table 1), it might be expected that the $\delta^{18} \mathrm{O}_{\text {water }} / \delta^{18} \mathrm{O}_{\text {tissue }}$ relationship should be consistently strong in comparison with $\delta^{2} \mathrm{H}_{\text {water }} / \delta^{2} \mathrm{H}_{\text {tissue }}$ relationships. However, in some cases the opposite pattern has been documented with strong relationships in $\delta^{2} \mathrm{H}_{\text {water }} / \delta^{2} \mathrm{H}_{\text {tissue }}$ comparisons and corresponding weaker relationships in the $\delta^{18} \mathrm{O}_{\text {water }} / \delta^{18} \mathrm{O}_{\text {tissue }}$ comparison, such as for passerine birds and aquatic insects (Hobson et al., 2004; Myers et al., 2012; Hobson and Koehler, 2015). Some potential contributors to the relatively poor relationship in $\delta^{18} \mathrm{O}$ values may be due to the exchanges of $\mathrm{O}$ in body water with $\mathrm{O}$ in the $\mathrm{CO}_{2}$ of dissolved body water (McCluney and Sabo, 2010), or that in aquatic organisms, organically bound oxygen, particularly

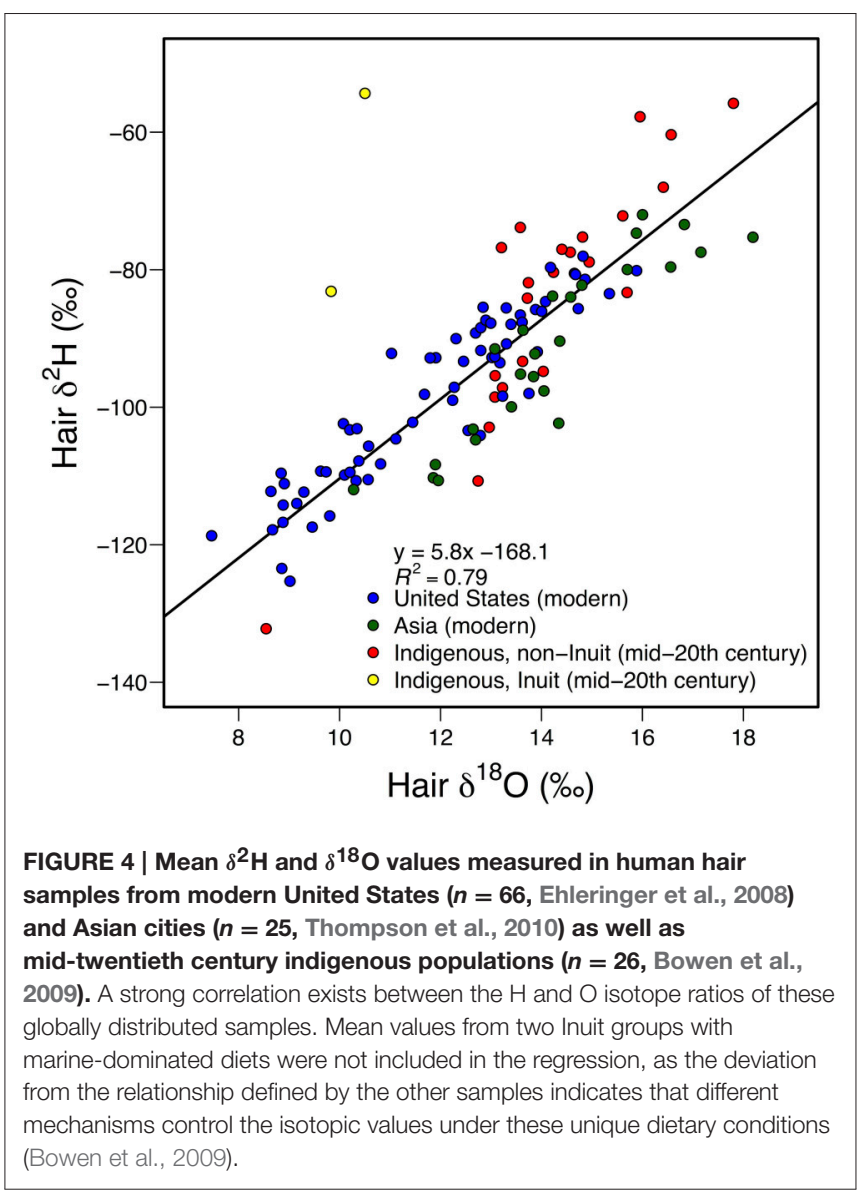

in carbonyl and carboxyl functional groups, can exchange with environmental water (Myers et al., 2012).

There are relatively few datasets in which both $\delta^{2} \mathrm{H}_{\text {tissue }}$ and $\delta^{18} \mathrm{O}_{\text {tissue }}$ values have been measured across a range of environmental water isotope values, and thus these types of comparisons are limited. Yet in some of these cases, both $\delta^{2} \mathrm{H}$ and $\delta^{18} \mathrm{O}$ values of tissue demonstrate a strong isotopic disequilibrium with environmental water. For example, the hair of carnivorous felids (pumas and bobcats) lack the expected correlation with isotopes in local water (Pietsch et al., 2011). One potential factor, in this case, may be high levels of animal protein consumption, which may contribute to low levels of amino acid synthesis and/or potential trophic level effects (discussed previously). In addition, felines drink to a limited extent, produce high levels of metabolic water, and excrete concentrated urine, suggesting that these differences in physiological and metabolic adaptations of carnivores contributed to the lack of correlation between hair and environmental water $\delta^{2} \mathrm{H}$ and $\delta^{18} \mathrm{O}$ values (Pietsch et al, 2011).

\section{CONSIDERATIONS AND CAVEATS}

As with other stable isotopes, the use of $\mathrm{H}$ and $\mathrm{O}$ in energy flow and food web studies requires attention to additional factors that can influence isotopic values, such as environmental variability 
over time, organismal and physiological characteristics, lipid content, and trophic compounding. Many of these caveats (highlighted in Figure 1 as factors that contribute to integration and measurement) are not unique to $\delta^{2} \mathrm{H}$ and $\delta^{18} \mathrm{O}$ data, but have also proven applicable to studies using $\delta^{13} \mathrm{C}$ and $\delta^{15} \mathrm{~N}$ as well. Here, we discuss some of the potential influences on $\mathrm{H}$ and $\mathrm{O}$ isotope values that researchers should be cognizant of when conducting food web studies.

\section{Environmental Variability}

The isotopic composition of meteoric, surface, and ground water can vary temporally (Kendall and Coplen, 2001; Bowen, 2008). In precipitation, the extent of the temporal variability in isotope values is spatially heterogeneous, and the highest intra-annual ranges occur in mid to high-latitude continental interiors as a result of seasonal variability (Bowen, 2008). In river water, seasonal shifts may occur in snow-dominated areas when melt water is released or the degree of river management varies (e.g., dams, irrigation return, diversions for agricultural, and urban use) (Kendall and Coplen, 2001). Characterizing how the environmental variability in the isotopic composition of water is then translated into the $\delta^{2} \mathrm{H}$ and $\delta^{18} \mathrm{O}$ values or organismal tissue is still being explored. Higher trophic-level organisms may act as ecological integrators, averaging isotopic fluctuations over time and dampening temporal variability in the environmental signal, as has been demonstrated for using $\delta^{13} \mathrm{C}$ values as a proxy for atmospheric $\mathrm{CO}_{2}$ in successive trophic levels (Bump et al., 2007). With respect to $\mathrm{H}$ and $\mathrm{O}$ isotopic composition between organisms and their environment, parallel shifts have been observed in some cases but not others. For example, seasonal shifts observed in the $\delta^{2} \mathrm{H}$ and $\delta^{18} \mathrm{O}$ values of hair in grazed livestock appear to be a good proxy for seasonal variability in climate (Auerswald et al., 2011; Zazzo et al., 2015), and in aquatic systems, invertebrates in prairie wetlands exhibited intra- and inter-annual variability in $\delta^{2} \mathrm{H}$ values that were related to the timing and amount of precipitation (Bortolotti et al., 2013). On the contrary, algal and invertebrate $\delta^{2} \mathrm{H}$ values were temporally consistent in a California river system despite changes in environmental conditions known to affect algal $\delta{ }^{13} \mathrm{C}$ values (Finlay et al., 2010). Thus, these patterns may be specific to location, ecosystem type, and species of study, but understanding the time frames over which organisms track changes in environmental $\delta^{2} \mathrm{H}_{\text {water }}$ and $\delta^{18} \mathrm{O}_{\text {water values is still in }}$ its infancy (Vander Zanden et al., 2014, 2015a; Tonra et al., 2015).

Other environmental factors such as climate and aridity have been demonstrated to influence the $\delta^{2} \mathrm{H}$ and $\delta^{18} \mathrm{O}$ values of organisms. Evaporative environments can affect both the degree of fractionation in dietary sources (i.e., plants) as well as the animal body water pool. When the tissue isotopic signal has a greater proportional contribution from diet, understanding the environmental drivers of variability within and among food items is important, yet has not received much investigation. Instead, the bulk of research on climatic factors has focused on resulting effects on the animal body water and tissue isotopic signals. For example, the degree of increase in $\delta^{2} \mathrm{H}$ values of rock dove (Columba livia) body water was related to the fraction of total water loss that occurred by evaporation (McKechnie et al., 2004). In addition, several herbivorous species have tissue $\delta^{18} \mathrm{O}$ values that correlate with measures of relative humidity and/or aridity (Ayliffe and Chivas, 1990; Luz et al., 1990; Cormie et al., 1994; Delgado Huertas et al., 1995; Levin et al., 2006), and bone collagen $\delta^{18} \mathrm{O}$ values were different between dry and moist forests in a variety of taxa (Crowley et al., 2015). Distinguishing between feeding habitats within a forest canopy (i.e., arboreal vs. terrestrial feeding heights) has also been evidenced in $\delta^{18} \mathrm{O}$ values of tissues such as tooth enamel and bone collagen, likely driven by stratification in plant isotopic composition as relative humidity changes within the canopy (Nelson, 2013; Crowley et al., 2015). On the other hand, insect body water $\delta^{2} \mathrm{H}$ and $\delta^{18} \mathrm{O}$ values were not affected by varying humidity and temperature (McCluney and Sabo, 2010), and several mammalian species were found to have tooth enamel $\delta^{18} \mathrm{O}$ values that were not sensitive to changes in aridity (Levin et al., 2006). Whether this divergence relates to physiological differences among organisms or other characteristics has not been determined.

\section{Physiological and Organismal Variability}

Other characteristics of an organism's life history, habitat, and physiology may result in variability in $\delta^{2} \mathrm{H}$ and $\delta^{18} \mathrm{O}$ values, including species, size, age class, trophic position, habitat stratification, drinking behavior, metabolic rate, routing, and tissue type (Tuross et al., 2008; Kirsanow and Tuross, 2011; Soto et al., 2011, 2013b; Wolf et al., 2011, 2012; Storm-Suke et al., 2012; Graham et al., 2013; Crowley et al., 2015).

Similar to patterns found with $\mathrm{C}$ and $\mathrm{N}$ isotopes (Roth and Hobson, 2000; Trueman et al., 2005; Reich et al., 2008; Martínez del Rio et al., 2009), it may be necessary to account for age class and growth rates when comparing $\mathrm{H}$ and $\mathrm{O}$ isotope values within or among species. Fish size-in addition to species and tissue type-influenced the proportion of ${ }^{2} \mathrm{H}$ in muscle derived from drinking water, and in turn the $\delta^{2} \mathrm{H}$ values of the tissue (Graham et al., 2013). In rodents, $\delta^{18} \mathrm{O}$ values of tooth enamel carbonate were not affected by ontogenetic factors, while $\delta^{2} \mathrm{H}$ and $\delta^{18} \mathrm{O}$ values of subcutaneous fat showed an age-class effect, such that the fat of young rats did not strongly reflect $\delta^{2} \mathrm{H}$ and $\delta^{18} \mathrm{O}$ values of drinking water (Kirsanow and Tuross, 2011). Likewise, fish growth rate had a significant influence on the protein and lipid $\delta^{2} \mathrm{H}$ values in fish muscle, suggesting that metabolic effects associated with growth may influence the degree of incorporation of products derived from dietary lipids to tissue $\mathrm{H}$ (Soto et al., $2013 \mathrm{~b})$. This suggests that $\delta^{2} \mathrm{H}$ values in lipids could provide complementary information to measuring $\delta^{2} \mathrm{H}$ values in protein in understanding organismal ecology, similar to the lipid $\delta^{2} \mathrm{H}$ biomarkers that have been important paleohydrological proxies for photosynthesizing organisms (Sachse et al., 2012).

Several related physiological factors important to fluxes of organismal $\mathrm{H}$ and $\mathrm{O}$, such as metabolic rate, total water flux, and evaporative water loss are largely influenced by body size when comparing across a wide range of taxa, yet each factor may respond to dietary, behavioral, and environmental influences within a species or similar group of organisms (some of the environmental influences are explored in the preceding section). Metabolic rate is closely linked to body size, but within organisms of similar body mass, it can be sensitive to factors such as 
diet and thermophysiology (Bryant and Froelich, 1995). For example, the relative contribution of drinking water to avian feather $\mathrm{H}$ increases with increasing metabolic rate, which was experimentally elevated by housing quail at colder temperatures (Storm-Suke et al., 2012). Total water flux, defined as the amount of water into and out of an animal each day, also scales with body size, but can respond to other factors, such as dietary inputs and environmental temperature (Bryant and Froelich, 1995). Species that derive much of their water from leaves are expected to have more ${ }^{18} \mathrm{O}$ - and ${ }^{2} \mathrm{H}$-enriched tissues, while "obligate drinkers" or species that rely on meteoric water that has experienced less evaporation than vegetative sources would have relatively lower $\delta^{2} \mathrm{H}$ and $\delta^{18} \mathrm{O}$ values (Flanagan and Ehleringer, 1991; Levin et al., 2006; Pietsch et al., 2011; Moritz et al., 2012). Similarly, evaporative water loss composes a portion of the water flux out of an animal, and can be influenced by temperature, activity level, and method of body temperature regulation. These factors can be intertwined, making it difficult to experimentally test cause and effect, though it may be possible to build physiological characteristics into modeling predictions of tissue isotopic composition.

Within an organism, inter- and intra- tissue variation can also influence sampling protocols and data interpretation. Inter-tissue differences are likely due to routing of dietary macromolecules and variability in the biochemical constituents (e.g., amino acids) of the tissues, which do not undergo uniform fractionation during synthesis (Tuross et al., 2008; Wolf et al., 2011). In a controlled, long-term feeding trial of pigs maintained on consistent diet and drinking water sources, a large isotopic range was observed across different tissues: over $200 \%$ in $\delta^{2} \mathrm{H}$ values and $8 \%$ in $\delta^{18} \mathrm{O}$ values (Tuross et al., 2008). Additionally, intratissue variability, or inherent variation, in stable isotope values within some tissues may be higher than in others. Values of $\delta^{18} \mathrm{O}$ in human nail samples were more variable than in scalp hair from the sample subjects (Fraser et al., 2006). In fishes, the least variability in $\delta^{2} \mathrm{H}$ values was observed in muscle compared to fin tissues, and therefore fin tissue should not be used unless the subsampling protocol is standardized or whole fins are homogenized prior to analysis (Graham et al., 2013; Hayden et al., 2015).

Another factor to consider in sample preparation is the presence of lipids, particularly in measuring $\delta^{2} \mathrm{H}$ values, as the ${ }^{2} \mathrm{H}$ content of lipids is typically much lower than that of proteinaceous tissues (Estep and Hoering, 1980; Hobson et al., 1999a; Soto et al., 2013c). For example, lipid $\delta^{2} \mathrm{H}$ values were up to $200 \%$ o lower than other tissues such as muscle, blood, hair, or bone collagen in mammals (Tuross et al., 2008; Kirsanow and Tuross, 2011) and 55-110\% lower than muscle and liver in fish (Soto et al., 2013b; Newsome et al., in review). The type of lipids present in a tissue may also affect the lipid isotopic composition, as different fats can be synthesized though varying biochemical pathways (Estep and Hoering, 1980; Zhang et al., 2009). Thus, tissues that have a high or variable proportion of lipids can affect the interpretation of $\delta^{2} \mathrm{H}$ values. Given the small magnitude of the $\delta^{2} \mathrm{H}$ shift observed across a variety of samples, a failure to correct for lipids affected mixing model results minimally (Wilkinson et al., 2015). However, if the lipid content differs between consumers and end members, there is a potential for some bias in the mixing model results (Wilkinson et al., 2015). In addition, the presence of lipids may affect the exchangeable $\mathrm{H}$ content and the interpretation of bulk $\delta^{2} \mathrm{H}$ values when the comparative equilibration method is used for $\delta^{2} \mathrm{H}$ analysis (Wassenaar and Hobson, 2000). More specifically, $\mathrm{H}$ in lipids is mainly bound to carbon and is not exchangeable with ambient water vapor at low temperatures, whereas $\mathrm{H}$ in proteins does exchange (Wassenaar and Hobson, 2000), and thus the overall lipid content can add variance to measured non-exchangeable $\delta^{2} \mathrm{H}$ values when the lipid proportion is variable among samples. As this field advances, there may also be utility in considering the isotopic composition of lipids in dietary items. Lipid-derived $\mathrm{H}$ can likely be used by eukaryotes to synthesis non-essential amino acids and construct proteinacious tissues, which has been shown to occur for $\mathrm{C}$ in lab mice that are fed diets 10-40\% lipid (by weight) (Newsome et al., 2014; Wolf et al., 2015). Nevertheless, lipid extraction is currently recommended to maximize accuracy of $\delta^{2} \mathrm{H}$ measurements and mixing model outputs.

\section{WHERE TO GO FROM HERE}

The measurement of $\delta^{2} \mathrm{H}$ and $\delta^{18} \mathrm{O}$ in the tissues of plants, wildlife, and people has emerged as a powerful tool, not only in the initial applications of tracking human/animal geographic origin and migration patterns, but also to understand the movement of energy and nutrients across ecosystem boundaries, food web relationships, and the physiologic status of organisms. Along with the exciting potential for scientific advances in ecosystem, food web, and organismal ecology, we have variable understanding of the mechanisms involved in integrating environmental water and dietary source $\mathrm{H}$ and $\mathrm{O}$ into organismal tissues illustrated in Figure 1. We highlight analytical considerations that will contribute to producing reliable analytical results across laboratories and identify knowledge gaps where continued investigation is encouraged.

\section{Analytical Considerations}

The first of these considerations is the need for quality assurance practices in $\mathrm{H}$ and $\mathrm{O}$ isotope measurements. Measurements of $\delta^{2} \mathrm{H}$ are particularly problematic, given the capacity for a portion of the $\mathrm{H}$ atoms to exchange with ambient humidity. The ambient air moisture can change with location, season, or even on a daily basis, affecting both the concentration and isotopic composition of the moisture. Thus, the fraction of exchangeable $\mathrm{H}$ must be accounted for (Wassenaar and Hobson, 2000; Bowen et al., 2005a; Landwehr et al., 2011; Meier-Augenstein et al., 2013). We have a fairly good understanding of the fact that $\mathrm{H}$ exchange occurs (Figure 1) in addition to analytical approaches to account for this phenomenon in measuring $\delta^{2} \mathrm{H}$ values. However, some studies have failed to account for $\mathrm{H}$ exchange or do not report adequate information about the methods used to do so. Approaches for controlled and repeatable accounting of the exchangeable- $\mathrm{H}$ in organic samples have varied (Wassenaar and Hobson, 2003; Bowen et al., 2005a; Kelly et al., 2009; MeierAugenstein et al., 2011; Qi and Coplen, 2011; Coplen and Qi, 2012). Some of the recommended methods are described in 
more detail by Meier-Augenstein et al. (2013) and include a two-stage exchange equilibration process (Bowen et al., 2005a), a comparative two-point end-member equilibration (Wassenaar and Hobson, 2000; Kelly et al., 2009), online comparative twopoint end-member equilibration with an autosampler that will allow steam equilibration (EuroVector ${ }^{1}$ ), or an online vacuum equilibration system (Wassenaar et al., 2015). Regardless of the method used, we emphasize that the methods must be reliable and reproducible, and reported with sufficient detail in publications. The interchange of materials among laboratories can aid in assuring repeatability in $\delta^{2} \mathrm{H}$ and $\delta^{18} \mathrm{O}$ measurements (e.g., Meier-Augenstein et al., 2011), given that it is unrealistic to expect that all laboratories are equipped in exactly the same way.

Another consideration related to the analytical quality assurance is the use of standards. Currently, no organic international standards for $\mathrm{H}$ exist, but laboratory standards that are used should be matched to the unknown sample type in terms of biochemical structure, as the sample composition can affect the proportion of exchangeable $\mathrm{H}$, which will affect equilibration calculations. Two human hair standards, USGS-42 and USGS43, of known and different isotopic composition are useful in the isotopic analysis of human scalp hair (Coplen and Qi, 2012), and two keratin standards, developed by Environment Canada (Wassenaar et al., 2015), and which can now be purchased through USGS, can be useful for other types of wildlife keratins. As laboratories develop their own internal standards, sharing among the community and referencing to non-exchangeable $\mathrm{H}$ isotopic values is encouraged.

Finally, we emphasize the importance of accounting for lipids, given their potential to affect $\delta^{2} \mathrm{H}$ values. Lipids have dramatically lower $\delta^{2} \mathrm{H}$ values due to fractionation during synthesis and integration, but this is an area where limited data are available (Figure 1). Few studies have compared $\delta^{2} \mathrm{H}$ values in lipidextracted vs. untreated organisms or tissues, and these studies have presented mixed conclusions. In producers and consumers of several lake species, lipid extraction had little effect on mixing model results using $\delta^{2} \mathrm{H}$ values, and therefore samples were not lipid extracted prior to analysis (Solomon et al., 2011). In contrast, other studies have recommended lipid extraction in order to best quantify consumer $\delta^{2} \mathrm{H}$ values (Jardine et al., 2009; Wilkinson et al., 2015). Across a variety of samples from lakes and rivers (four end member groups and three consumer groups), the mean change in $\delta^{2} \mathrm{H}$ values after lipid extraction was $11.8 \%$, though the overall change in $\delta^{2} \mathrm{H}$ values $\left(\Delta^{2} \mathrm{H}\right)$ after lipid extraction varied among species (with algae changing the least) (Wilkinson et al., 2015). While lipids have substantially lower $\delta^{2} \mathrm{H}$ values than proteins, they have been found be highly correlated with $\delta^{2} \mathrm{H}$ values of environmental water (Hobson et al., 1999a; Soto et al., 2013c). Therefore, it might be expected that the magnitude of the $\delta^{2} \mathrm{H}$ shift is related to the lipid content of the tissue, yet the degree of $\delta^{2} \mathrm{H}$ shifts was not related to $\mathrm{C}: \mathrm{N}$ values in untreated samples (Wilkinson et al., 2015).

$\mathrm{C}: \mathrm{N}$ ratios have been the typical proxy for lipid content used in correcting $\delta^{13} \mathrm{C}$ values for animal tissue, although the

${ }^{1}$ EuroVector. Available at: http://www.eurovector.it/index.html [Accessed October 28, 2015]. relationship between $\mathrm{C}: \mathrm{N}$ and lipid content is not significant for some food web components such as plants (Post et al., 2007). Models have been developed to mathematically correct for the presence of lipids when measuring $\delta^{13} \mathrm{C}$ values (Post et al., 2007). Additional laboratory studies may allow for the development of similar models for $\delta^{2} \mathrm{H}$ values in the future, potentially using measures of weight percent $\mathrm{H}$ content as a proxy for assessing lipid effects on $\delta^{2} \mathrm{H}$ values, but no reliable correction models currently exist. Lipid extraction or other normalization methods will be most important when the lipid content is variable among samples (e.g., consumers and end members) to reduce the potential for bias in $\delta^{2} \mathrm{H}$ values.

\section{Knowledge Gaps}

Characterizing the difference between $\delta^{2} \mathrm{H}$ values of terrestrial vegetation and aquatic primary producers is critical for quantifying the proportional energy inputs into aquatic food webs (Figure 2). Thus, far, characterization of primary producer $\delta^{2} \mathrm{H}$ values has been required at each study site, as the differences may be unique to each location or habitat. For example, the $\delta^{2} \mathrm{H}$ offset between terrestrial and aquatic producers was much larger in an arid environment (Doucett et al., 2007) than a mesic one (Jardine et al., 2009). The application of models to predict $\delta^{2} \mathrm{H}$ values of these two end members could be useful but has not been directly explored. This could be achieved in the following steps. Meteoric water isotopic composition can be estimated for a given location using modeling tools such as IsoMAP (Bowen et al., 2013), and conversions between $\delta^{2} \mathrm{H}_{\text {water }}$ values and $\delta^{2} \mathrm{H}_{\mathrm{om}}$ values can be measured for the species of primary producers of interest since the $\delta^{2} \mathrm{H}$ variability among species from the same producer group and ecosystem is relatively large (Hondula et al., 2014). However, the estimates for $\delta^{2} \mathrm{H}_{\mathrm{om}}$ values in terrestrial vegetation could be improved by accounting for site-specific evapotranspiration among regions of differing aridity and validated with data from the growing number of sites where these measurements have been made. Soon, IsoMAP users will be able to estimate $\delta^{2} \mathrm{H}$ values for water of plant leaves, which could aid in exploring the controls on terrestrial vs. aquatic vegetation offset and how this differs among sites. Alternatively, a mechanistic model to predict the isotopic composition of plant tissue, such as the one developed for tree-ring cellulose accounting for humidity and source water environmental data (Roden et al., 2000) could be useful for predicting terrestrial leaf and aquatic primary producer isotopic composition.

As research using $\delta^{2} \mathrm{H}$ and $\delta^{18} \mathrm{O}$ values in food web ecology continues to expand, we expect that controlled studies to explore the mechanisms and physiological processes affecting the isotopic values of $\mathrm{H}$ and $\mathrm{O}$ during the integration and synthesis of tissues will contribute to advances in interpreting isotopic data (Figure 1). It is not yet clear whether the mechanistic models that describe the behavior of $\mathrm{H}$ and $\mathrm{O}$ isotope behavior in humans, primates, rodents, and fish (Ehleringer et al., 2008; Podlesak et al., 2008; Bowen et al., 2009; O'Grady et al., 2012; Soto et al., 2013c) can be applied to other organisms or tissues, but work that focuses on the theoretical underpinnings of the expected tissue values given known diet and environmental water inputs would be valuable. 
It may also be important to account for organismal differences in physiological characteristics such as metabolic rate, water flux, and evaporative losses in modeling and predicting $\delta^{2} \mathrm{H}$ and $\delta^{18} \mathrm{O}$ values (Figure 1). These factors, along with behavior, may largely determine the relative contribution of diet vs. environmental water contribution to tissue measurements. The drinking water status of organisms should be further explored with respect to $\mathrm{H}$ and $\mathrm{O}$ isotope composition in tissues. When small portions of the body water are derived from drinking water, there appears to be a decoupling between tissue and environmental water isotopic composition, or at least this effect was observed in felids (Pietsch et al., 2011). Experiments with organisms that represent a spectrum of water-conservation strategies (e.g., obligate drinkers vs. drought-tolerant species) would elucidate if this phenomenon extends beyond felids. Additionally, the effect of exercise (or metabolic rate changes) and increased evapotranspiration on the dynamics of the body water pool is poorly understood. The metabolic demands and evaporative water loss associated with growing tissue during the breeding season may contribute to deviations between feather and precipitation $\delta^{2} \mathrm{H}$ values of raptors (Meehan et al., 2003; Smith et al., 2008). Yet the water loss associated with evaporative environments (i.e., high temperatures and/or low environmental humidity) does not have consistent effects on organismal tissue $\delta^{2} \mathrm{H}$ and $\delta^{18} \mathrm{O}$ values (Ayliffe and Chivas, 1990; Luz et al., 1990; Delgado Huertas et al., 1995; McCluney and Sabo, 2010), and may be related to body size or mass-specific metabolic rates (Topalov et al., 2013). More controlled experiments are needed to determine how environmental conditions, in addition to diet and water inputs, may affect organismal body water and tissue $\mathrm{H}$ and $\mathrm{O}$ isotopic composition.

Additionally, little is known about the turnover times for $\mathrm{H}$ and $\mathrm{O}$ isotopes (Podlesak et al., 2008; Storm-Suke et al., 2012; Wolf et al., 2012), which is necessary to quantify the time frames over which organisms reflect changes in the diet, drinking water, and environment. Controlled feeding studies with changes in diet and/or drinking water are needed to characterize the integration periods and turnover patterns of these elements in organismal tissue. General patterns of turnover rates using C, N, and $S$ isotopes from a synthesis of many studies indicated that half-life is related to animal body mass (Vander Zanden et al., 2015b), though insufficient data exist to explore whether similar patterns exist for $\mathrm{H}$ and $\mathrm{O}$ isotopes. Molecular routing may be largely responsible for tissue-specific differences in $\delta^{2} \mathrm{H}$ and $\delta^{18} \mathrm{O}$ values, and feeding trials that account for particular dietary components can help to explore routing effects. In addition, compound-specific $\delta^{2} \mathrm{H}$ analysis of individual amino acids may

\section{REFERENCES}

Auerswald, K., Rossmann, A., Schäufele, R., Schwertl, M., Monahan, F. J., and Schnyder, H. (2011). Does natural weathering change the stable isotope composition $\left({ }^{2} \mathrm{H},{ }^{13} \mathrm{C},{ }^{15} \mathrm{~N},{ }^{18} \mathrm{O}\right.$ and $\left.{ }^{34} \mathrm{~S}\right)$ of cattle hair? Rapid Commun. Mass Spectrom. 25, 3741-3748. doi: 10.1002/rcm.5284

Ayliffe, L. K., and Chivas, A. R. (1990). Oxygen isotope composition of the bone phosphate of Australian kangaroos: potential as a palaeoenvironmental also provide insights with respect to the dietary resources that contribute to bulk $\delta^{2} \mathrm{H}$ values (Fogel et al., 2010; Wolf et al., 2012).

Finally, the underlying causes and consistency of trophic effect on $\delta^{2} \mathrm{H}$ values, particularly in terrestrial organisms, remains an area of uncertainty. Limited evidence suggests that $\delta^{2} \mathrm{H}$ values reflect trophic level (Birchall et al., 2005; Peters et al., 2012; Topalov et al., 2013), but the degree to which this pattern reflects trophic compounding of environmental water contributions vs. metabolic fractionation is not yet clear. The power of $\delta^{15} \mathrm{~N}$ values to estimate trophic position has been applied widely (Post, 2002), and if further evidence were to support a trophic basis to $\delta^{2} \mathrm{H}$ values, it would provide a powerful addition to the toolbox. Therefore, controlled studies focused on trophic processes (Figure 1) would help to address knowledge gaps in the ability to use $\delta^{2} \mathrm{H}$ values as a trophic level indicator.

\section{CONCLUSIONS}

Despite the research needs in this field, there is considerable potential to use $\mathrm{H}$ and $\mathrm{O}$ isotopes to trace the source and diet of consumers and to infer the role of environmental waters in terrestrial and aquatic systems. We believe that methodological consistency, controlled experimentation, and theoretical modeling can lead to progress in using these nontraditional stable isotopes in ecological studies. Nevertheless, the addition of $\delta^{2} \mathrm{H}$ and $\delta^{18} \mathrm{O}$ measurements to the isotopic toolbox enriches the capabilities of using biogeochemical markers to illuminate patterns in the study of complex food web relationships.

\section{AUTHOR CONTRIBUTIONS}

All authors contributed to the conceptual ideas, writing, and editing of this work, and approved it for publication.

\section{ACKNOWLEDGMENTS}

This work was supported by the Inter-university Training for Continental Scale Ecology (ITCE) program sponsored by the National Science Foundation (EF-1241286). KH was supported by an operating grant from Environment Canada. DS was supported by a post-doctoral fellowship from the Natural Sciences and Engineering Research Council of Canada and Environment Canada. The authors would like to thank Seth Newsome and Don Phillips for comments that improved the manuscript. recorder. Geochim. Cosmochim. Acta 54, 2603-2609. doi: 10.1016/00167037(90)90246-H

Babler, A. L., Pilati, A., and Vanni, M. J. (2011). Terrestrial support of detritivorous fish populations decreases with watershed size. Ecosphere 2, art76. doi: 10.1890/ES11-00043.1

Batt, R. D., Carpenter, S. R., Cole, J. J., Pace, M. L., Cline, T. J., Johnson, R. A., et al. (2012). Resources supporting the food web of a naturally productive lake. Limnol. Oceanogr. 57, 1443-1452. doi: 10.4319/lo.2012.57.5.1443 
Batt, R. D., Carpenter, S. R., Cole, J. J., Pace, M. L., Johnson, R. A., Kurtzweil, J. T., et al. (2015). Altered energy flow in the food web of an experimentally darkened lake. Ecosphere 6, art33. doi: 10.1890/ES14-00241.1

Baxter, C. V., Fausch, K. D., and Carl Saunders, W. (2005). Tangled webs: reciprocal flows of invertebrate prey link streams and riparian zones. Freshw. Biol. 50, 201-220. doi: 10.1111/j.1365-2427.2004.01328.x

Bearhop, S., Adams, C. E., Waldron, S., Fuller, R. A., and Macleod, H. (2004). Determining trophic niche width: a novel approach using stable isotope analysis. J. Anim. Ecol. 73, 1007-1012. doi: 10.1111/j.0021-8790.2004.00861.x

Berggren, M., Bergström, A.-K., and Karlsson, J. (2015). Intraspecific autochthonous and allochthonous resource use by zooplankton in a humic lake during the transitions between winter, summer and fall. PLoS ONE 10:e0120575. doi: 10.1371/journal.pone.0120575

Berggren, M., Ziegler, S. E., St-Gelais, N. F., Beisner, B. E., and Del Giorgio, P. A. (2014). Contrasting patterns of allochthony among three major groups of crustacean zooplankton in boreal and temperate lakes. Ecology 95, 1947-1959. doi: 10.1890/13-0615.1

Birchall, J., O'Connell, T. C., Heaton, T. H. E., and Hedges, R. E. M. (2005). Hydrogen isotope ratios in animal body protein reflect trophic level. J. Anim. Ecol. 74, 877-881. doi: 10.1111/j.1365-2656.2005.00979.x

Boecklen, W. J., Yarnes, C. T., Cook, B. A., and James, A. C. (2011). On the use of stable isotopes in trophic ecology. Annu. Rev. Ecol. Evol. Syst. 42, 411-440. doi: 10.1146/annurev-ecolsys-102209-144726

Bortolotti, L. E., Clark, R. G., and Wassenaar, L. I. (2013). Hydrogen isotope variability in prairie wetland systems: implications for studies of migratory connectivity. Ecol. Appl. 23, 110-121. doi: 10.1890/12-0232.1

Bowen, G. J. (2008). Spatial analysis of the intra-annual variation of precipitation isotope ratios and its climatological corollaries. J. Geophys. Res. Atmospheres 113, D05113. doi: 10.1029/2007jd009295

Bowen, G. J., Chesson, L., Nielson, K., Cerling, T. E., and Ehleringer, J. R. (2005a). Treatment methods for the determination of $\delta^{2} \mathrm{H}$ and $\delta^{18} \mathrm{O}$ of hair keratin by continuous-flow isotope-ratio mass spectrometry. Rapid Commun. Mass Spectrom. 19, 2371-2378. doi: 10.1002/rcm.2069

Bowen, G. J., Ehleringer, J. R., Chesson, L. A., Thompson, A. H., Podlesak, D. W., and Cerling, T. E. (2009). Dietary and physiological controls on the hydrogen and oxygen isotope ratios of hair from mid-20th century indigenous populations. Am. J. Phys. Anthropol. 139, 494-504. doi: 10.1002/ajpa.21008

Bowen, G. J., Kennedy, C. D., Liu, Z., and Stalker, J. (2011). Water balance model for mean annual hydrogen and oxygen isotope distributions in surface waters of the contiguous United States. J. Geophys. Res. Biogeosciences 116, G04011. doi: 10.1029/2010jg001581

Bowen, G. J., Wassenaar, L. I., and Hobson, K. A. (2005b). Global application of stable hydrogen and oxygen isotopes to wildlife forensics. Oecologia 143, 337-348. doi: 10.1007/s00442-004-1813-y

Bowen, G. J., West, J. B., Miller, C. C., Zhao, L., and Zhang, T. (2013). IsoMAP: Isoscapes Modeling, Analysis and Prediction (version 1.0). IsoMAP Proj. Available online at: http://isomap.org

Bryant, D. J., and Froelich, P. N. (1995). A model of oxygen isotope fractionation in body water of large mammals. Geochim. Cosmochim. Acta 59, 4523-4537. doi: 10.1016/0016-7037(95)00250-4

Bump, J. K., Fox-Dobbs, K., Bada, J. L., Koch, P. L., Peterson, R. O., and Vucetich, J. A. (2007). Stable isotopes, ecological integration and environmental change: wolves record atmospheric carbon isotope trend better than tree rings. Proc. $R$. Soc. B Biol. Sci. 274, 2471-2480. doi: 10.1098/rspb.2007.0700

Caut, S., Angulo, E., and Courchamp, F. (2009). Variation in discrimination factors $\left(\Delta^{15} \mathrm{~N}\right.$ and $\left.\Delta^{13} \mathrm{C}\right)$ : the effect of diet isotopic values and applications for diet reconstruction. J. Appl. Ecol. 46, 443-453. doi: 10.1111/j.13652664.2009.01620.x

Chesson, L. A., Valenzuela, L. O., Bowen, G. J., Cerling, T. E., and Ehleringer, J. R. (2011). Consistent predictable patterns in the hydrogen and oxygen stable isotope ratios of animal proteins consumed by modern humans in the USA. Rapid Commun. Mass Spectrom. 25, 3713-3722. doi: 10.1002/rcm.5283

Clark, I. D., and Fritz, P. (1997). Environmental Isotopes in Hydrogeology. London: CRC Press.

Cole, J. J., Carpenter, S. R., Kitchell, J., Pace, M. L., Solomon, C. T., and Weidel, B. (2011). Strong evidence for terrestrial support of zooplankton in small lakes based on stable isotopes of carbon, nitrogen, and hydrogen. Proc. Natl. Acad. Sci. U.S.A. 108, 1975-1980. doi: 10.1073/pnas.1012807108
Cole, J. J., and Solomon, C. T. (2012). Terrestrial support of zebra mussels and the Hudson River food web: a multi-isotope, Bayesian analysis. Limnol. Oceanogr. 57, 1802-1815. doi: 10.4319/lo.2012.57.6.1802

Collins, S. M., Kohler, T. J., Thomas, S. A., Fetzer, W. W., and Flecker, A. S. (in press). The importance of terrestrial subsidies in stream food webs varies along a stream size gradient. Oikos. doi: 10.1111/oik.02713

Cooper, S. D., Page, H. M., Wiseman, S. W., Klose, K., Bennett, D., Even, T., et al. (2015). Physicochemical and biological responses of streams to wildfire severity in riparian zones. Freshw. Biol. 60, 2600-20619. doi: 10.1111/fwb.12523

Coplen, T. B., and Qi, H. (2012). USGS42 and USGS43: human-hair stable hydrogen and oxygen isotopic reference materials and analytical methods for forensic science and implications for published measurement results. Forensic Sci. Int. 214, 135-141. doi: 10.1016/j.forsciint.2011.07.035

Cormie, A. B., Luz, B., and Schwarcz, H. P. (1994). Relationship between the hydrogen and oxygen isotopes of deer bone and their use in the estimation of relative humidity. Geochim. Cosmochim. Acta 58, 3439-3449. doi: 10.1016/0016-7037(94)90097-3

Craig, H. (1961). Isotopic variations in meteoric waters. Science 133, 1702-1703. doi: 10.1126/science.133.3465.1702

Crait, J. R., and Ben-David, M. (2007). Effects of river otter activity on terrestrial plants in trophically altered Yellowstone Lake. Ecology 88, 1040-1052. doi: 10.1890/06-0078

Crowley, B. E., Melin, A. D., Yeakel, J. D., and Dominy, N. J. (2015). Do oxygen isotope values in collagen reflect the ecology and physiology of neotropical mammals? Front. Ecol. Evol. 3:127. doi: 10.3389/fevo.2015. 00127

Dawson, T. E., and Seigwolf, R. (2007). Stable Isotopes as Indicators of Ecological Change, 1st Edn. San Diego, CA: Elsevier Academic Press.

Deines, P., Wooller, M. J., and Grey, J. (2009). Unravelling complexities in benthic food webs using a dual stable isotope (hydrogen and carbon) approach. Freshw. Biol. 54, 2243-2251. doi: 10.1111/j.1365-2427.2009.02259.x

Dekar, M. P., King, R. S., Back, J. A., Whigham, D. F., and Walker, C. M. (2011). Allochthonous inputs from grass-dominated wetlands support juvenile salmonids in headwater streams: evidence from stable isotopes of carbon, hydrogen, and nitrogen. Freshw. Sci. 31, 121-132. doi: 10.1899/11-016.1

Delgado Huertas, A., Iacumin, P., Stenni, B., Sánchez Chillón, B., and Longinelli, A. (1995). Oxygen isotope variations of phosphate in mammalian bone and tooth enamel. Geochim. Cosmochim. Acta 59, 4299-4305. doi: 10.1016/00167037(95)00286-9

DeNiro, M. J., and Epstein, S. (1981a). Hydrogen isotope ratios of mouse tissues are influenced by a variety of factors other than diet. Science 214, 1374-1376. doi: 10.1126/science.7313700

DeNiro, M. J., and Epstein, S. (1981b). Influence of diet on the distribution of nitrogen isotopes in animals. Geochim. Cosmochim. Acta 45, 341-351. doi: 10.1016/0016-7037(81)90244-1

Doucett, R. R., Marks, J. C., Blinn, D. W., Caron, M., and Hungate, B. A. (2007). Measuring terrestrial subsidies to aquatic food webs using stable isotopes of hydrogen. Ecology 88, 1587-1592. doi: 10.1890/06-1184

Doucett, R. R., Power, G., Barton, D. R., Drimmie, R. J., and Cunjak, R. A. (1996). Stable isotope analysis of nutrient pathways leading to Atlantic salmon. Can. J. Fish. Aquat. Sci. 53, 2058-2066. doi: 10.1139/f96-132

Ehleringer, J. R., Bowen, G. J., Chesson, L. A., West, A. G., Podlesak, D. W., and Cerling, T. E. (2008). Hydrogen and oxygen isotope ratios in human hair are related to geography. Proc. Natl. Acad. Sci. U.S.A. 105, 2788-2793. doi: $10.1073 /$ pnas.0712228105

Elton, C. S. (1927). Animal Ecology. New York, NY: Macmillan.

Emery, K. A., Wilkinson, G. M., Ballard, F. G., and Pace, M. L. (2015). Use of allochthonous resources by zooplankton in reservoirs. Hydrobiologia 758, 257-269. doi: 10.1007/s10750-015-2338-6

Emery, K. A., Wilkinson, G. M., Camacho-Ibar, V. F., Pace, M. L., McGlathery, K. J., Sandoval-Gil, J. M., et al. (in press). Resource use of an aquacultured oyster (Crassostrea gigas) in the reverse estuary Bahía San Quintín, Baja California, México. Estuaries Coasts. doi: 10.1007/s12237-015-0021-9

Estep, M. F., and Dabrowski, H. (1980). Tracing food webs with stable hydrogen isotopes. Science 209, 1537-1538. doi: 10.1126/science.209.4464.1537

Estep, M. F., and Hoering, T. C. (1980). Biogeochemistry of the stable hydrogen isotopes. Geochim. Cosmochim. Acta 44, 1197-1206. doi: 10.1016/00167037(80)90073-3 
Evans, T. M. (2012). Assessing Food and Nutritional Resources of Native and Invasive Lamprey Larvae Using Natural Abundance Isotopes. Master thesis, The Ohio State University, Columbus, $\mathrm{OH}$.

Evaristo, J., Jasechko, S., and McDonnell, J. J. (2015). Global separation of plant transpiration from groundwater and streamflow. Nature 525, 91-94. doi: 10.1038/nature14983

Finlay, J. C. (2001). Stable-carbon-isotope ratios of river biota: implications for energy flow in lotic food webs. Ecology 82, 1052-1064. doi: 10.2307/2679902

Finlay, J. C. (2004). Patterns and controls of lotic algal stable carbon isotope ratios. Limnol. Oceanogr. 49, 850-861. doi: 10.4319/lo.2004.49.3.0850

Finlay, J. C., Doucett, R. R., and McNeely, C. (2010). Tracing energy flow in stream food webs using stable isotopes of hydrogen. Freshw. Biol. 55, 941-951. doi: 10.1111/j.1365-2427.2009.02327.x

Finlay, J. C., and Kendall, C. (2007). "Stable isotope tracing of temporal and spatial variability in organic matter sources to freshwater ecosystems," in Stable Isotopes in Ecology and Environmental Science, eds R. Michener and K. Lajtha (Malden, MA: Blackwell Publishing Ltd.), 283-333.

Finlay, J. C., Khandwala, S., and Power, M. E. (2002). Spatial scales of carbon flow in a river food web. Ecology 83, 1845-1859. doi: 10.1890/00129658(2002)083[1845:SSOCFI]2.0.CO;2

Finlay, J. C., Power, M. E., and Cabana, G. (1999). Effects of water velocity on algal carbon isotope ratios: implications for river food web studies. Limnol. Oceanogr. 44, 1198-1203. doi: 10.4319/lo.1999.44.5.1198

Flanagan, L. B., and Ehleringer, J. R. (1991). Stable isotope composition of stem and leaf water: applications to the study of plant water use. Funct. Ecol. 5, 270-277. doi: $10.2307 / 2389264$

Fogel, M. L., Griffin, P., and Newsome, S. D. (2010). "Compound specific hydrogen isotope analysis of amino acids from microbes: new biosignatures," in Astrobiology Science Conference (League City, TX), LPI Contribution 1538.

Foley, C. J., Bowen, G. J., Nalepa, T. F., Sepúlveda, M. S., and Höök, T. O. (2014). Stable isotope patterns of benthic organisms from the Great Lakes region indicate variable dietary overlap of Diporeia spp. and dreissenid mussels. Can. J. Fish. Aquat. Sci. 71, 1784-1795. doi: 10.1139/cjfas-2013-0620

France, R. (1995). Critical examination of stable isotope analysis as a means for tracing carbon pathways in stream ecosystems. Can. J. Fish. Aquat. Sci. 52, 651-656. doi: 10.1139/f95-065

Fraser, I., Meier-Augenstein, W., and Kalin, R. M. (2006). The role of stable isotopes in human identification: a longitudinal study into the variability of isotopic signals in human hair and nails. Rapid Commun. Mass Spectrom. 20, 1109-1116. doi: $10.1002 / \mathrm{rcm} .2424$

Fry, B. (2006). Stable Isotope Ecology. New York, NY: Springer Science.

Fry, B. (2013). Alternative approaches for solving underdetermined isotope mixing problems. Mar. Ecol. Prog. Ser. 472, 1-13. doi: 10.3354/meps10168

Graham, C. T., Harrison, S. S. C., and Harrod, C. (2013). Differences in the contributions of dietary water to the hydrogen stable isotope ratios of cultured Atlantic salmon and Arctic charr tissues. Hydrobiologia 721, 45-55. doi: 10.1007/s10750-013-1636-0

Gretebeck, R. J., Schoeller, D. A., Socki, R. A., Davis-Street, J., Gibson, E. K., Schulz, L. O., et al. (1997). Adaptation of the doubly labeled water method for subjects consuming isotopically enriched water. J. Appl. Physiol. 82, 563-570.

Grey, J. (2016). The incredible lightness of being methane-fuelled: stable isotopes reveal alternative energy pathways in aquatic ecosystems and beyond. Front. Ecol. Evol. 4:8. doi: 10.3389/fevo.2016.00008

Grey, J., and Deines, P. (2005). Differential assimilation of methanotrophic and chemoautotrophic bacteria by lake chironomid larvae. Aquat. Microb. Ecol. 40, 61-66. doi: 10.3354/ame040061

Grey, J., Jones, R. I., and Sleep, D. (2001). Seasonal changes in the importance of the source of organic matter to the diet of zooplankton in Loch Ness, as indicated by stable isotope analysis. Limnol. Oceanogr. 46, 505-513. doi: 10.4319/lo.2001.46.3.0505

Hayden, B., Soto, D. X., Jardine, T. D., Graham, B. S., Cunjak, R. A., Romakkaniemi, A., et al. (2015). Small tails tell tall tales - intra-individual variation in the stable isotope values of fish fin. PLOS ONE 10:e145154. doi: 10.1371/journal.pone.0145154

Helfield, J. M., and Naiman, R. J. (2001). Effects of salmon-derived nitrogen on riparian forest growth and implications for stream productivity. Ecology 82, 2403-2409. doi: 10.1890/0012-9658(2001)082[2403:EOSDNO] 2.0.CO;2
Hill, W. R., and Middleton, R. G. (2006). Changes in carbon stable isotope ratios during periphyton development. Limnol. Oceanogr. 51, 2360-2369. doi: 10.4319/lo.2006.51.5.2360

Hobson, K. A., Atwell, L., and Wassenaar, L. I. (1999a). Influence of drinking water and diet on the stable-hydrogen isotope ratios of animal tissues. Proc. Natl. Acad. Sci. U.S.A. 96, 8003-8006. doi: 10.1073/pnas.96. 14.8003

Hobson, K. A., Bowen, G. J., Wassenaar, L. I., Ferrand, Y., and Lormee, H. (2004). Using stable hydrogen and oxygen isotope measurements of feathers to infer geographical origins of migrating European birds. Oecologia 141, 477-488. doi: 10.1007/s00442-004-1671-7

Hobson, K. A., and Clark, R. G. (1992). Assessing avian diets using stable isotopes II: factors influencing diet-tissue fractionation. Condor 94, 189-197. doi: $10.2307 / 1368808$

Hobson, K. A., and Koehler, G. (2015). On the use of stable oxygen isotope $\left(\delta^{18} \mathrm{O}\right)$ measurements for tracking avian movements in North America. Ecol. Evol. 5, 799-806. doi: 10.1002/ece3.1383

Hobson, K. A., and Wassenaar, L. I. (eds.). (2008). Tracking Animal Migration with Stable Isotopes. Amsterdam: Elsevier. Eds.

Hobson, K. A., Wassenaar, L. I., and Taylor, O. R. (1999b). Stable isotopes ( $\delta \mathrm{D}$ and $\delta^{13} \mathrm{C}$ ) are geographic indicators of natal origins of monarch butterflies in eastern North America. Oecologia 120, 397-404. doi: 10.1007/s0044200 50872

Hondula, K. L., and Pace, M. L. (2014). Macroalgal support of cultured hard clams in a low nitrogen coastal lagoon. Mar. Ecol. Prog. Ser. 498, 187-201. doi: 10.3354/meps10644

Hondula, K. L., Pace, M. L., Cole, J. J., and Batt, R. D. (2014). Hydrogen isotope discrimination in aquatic primary producers: implications for aquatic food web studies. Aquat. Sci. 76, 217-229. doi: 10.1007/s00027-0130331-6

Hussey, N. E., MacNeil, M. A., McMeans, B. C., Olin, J. A., Dudley, S. F. J., Cliff, G., et al. (2014). Rescaling the trophic structure of marine food webs. Ecol. Lett. 17, 239-250. doi: 10.1111/ele.12226

Jackson, A. L., Inger, R., Parnell, A. C., and Bearhop, S. (2011). Comparing isotopic niche widths among and within communities: SIBER - Stable Isotope Bayesian Ellipses in R. J. Anim. Ecol. 80, 595-602. doi: 10.1111/j.1365-2656.2011. 01806.x

Jardine, T. D., Kidd, K. A., and Cunjak, R. A. (2009). An evaluation of deuterium as a food source tracer in temperate streams of eastern Canada. J. North Am. Benthol. Soc. 28, 885-893. doi: 10.1899/09-046.1

Junger, M., and Planas, D. (1994). Quantitative use of stable carbon isotope analysis to determine the trophic base of invertebrate communities in a boreal forest lotic system. Can. J. Fish. Aquat. Sci. 51, 52-61. doi: 10.1139/f94-007

Karasov, W. H., and Martínez del Rio, C. (2007). Physiological Ecology: How Animals Process Energy, Nutrients, and Toxins. Princeton, NJ: Princeton University Press.

Karlsson, J., Berggren, M., Ask, J., Byström, P., Jonsson, A., Laudon, H., et al. (2012). Terrestrial organic matter support of lake food webs: evidence from lake metabolism and stable hydrogen isotopes of consumers. Limnol. Oceanogr. 57, 1042-1048. doi: 10.4319/lo.2012.57.4.1042

Kelly, J. F., Bridge, E. S., Fudickar, A. M., and Wassenaar, L. I. (2009). A test of comparative equilibration for determining non-exchangeable stable hydrogen isotope values in complex organic materials. Rapid Commun. Mass Spectrom. 23, 2316-2320. doi: $10.1002 / \mathrm{rcm} .4150$

Kendall, C., and Coplen, T. B. (2001). Distribution of oxygen-18 and deuterium in river waters across the United States. Hydrol. Process. 15, 1363-1393. doi: 10.1002/hyp. 217

Kirsanow, K., and Tuross, N. (2011). Oxygen and hydrogen isotopes in rodent tissues: impact of diet, water and ontogeny. Palaeogeogr. Palaeoclimatol. Palaeoecol. 310, 9-16. doi: 10.1016/j.palaeo.2011.03.022

Kitchell, J. F., Schindler, D. E., Herwig, B. R., Post, D. M., Olson, M. H., and Oldham, M. (1999). Nutrient cycling at the landscape scale: the role of diel foraging migrations by geese at the Bosque del Apache National Wildlife Refuge, New Mexico. Limnol. Oceanogr. 44, 828-836. doi: 10.4319/lo.1999.44.3_part_2.0828

Kohn, M. J. (1996). Predicting animal $\delta^{18} \mathrm{O}$ : accounting for diet and physiological adaptation. Geochim. Cosmochim. Acta 60, 4811-4829. doi: 10.1016/S00167037(96)00240-2 
Kreuzer-Martin, H. W., Ehleringer, J. R., and Hegg, E. L. (2005). Oxygen isotopes indicate most intracellular water in log-phase Escherichia coli is derived from metabolism. Proc. Natl. Acad. Sci. U.S.A. 102, 17337-17341. doi: 10.1073/pnas.0506531102

Krouse, H. R., and Grineko, V. A. (eds.). (1971). Stable Isotopes: Natural and Anthropogenic Sulphur in the Environment. New York, NY: John Wiley \& Sons.

Lajtha, K., and Michener, R. (1994). Stable Isotopes in Ecology and Environmental Science. Oxford: Blackwell Scientific.

Landwehr, J. M., Meier-Augenstein, W., and Kemp, H. F. (2011). A counterintuitive approach to calculating non-exchangeable ${ }^{2} \mathrm{H}$ isotopic composition of hair: treating the molar exchange fraction $\mathrm{f}_{E}$ as a process-related rather than compound-specific variable. Rapid Commun. Mass Spectrom. 25, 301-306. doi: $10.1002 / \mathrm{rcm} .4854$

Layman, C. A., Araujo, M. S., Boucek, R., Hammerschlag-Peyer, C. M., Harrison, E., Jud, Z. R., et al. (2012). Applying stable isotopes to examine foodweb structure: an overview of analytical tools. Biol. Rev. 87, 545-562. doi: 10.1111/j.1469-185X.2011.00208.x

Layman, C. A., Arrington, D. A., Montaña, C. G., and Post, D. M. (2007). Can stable isotope ratios provide for communitywide measures of trophic structure? Ecology 88, 42-48. doi: 10.1890/0012-9658(2007)88[42:CSIRPF]2.0.CO;2

Levin, N. E., Cerling, T. E., Passey, B. H., Harris, J. M., and Ehleringer, J. R. (2006). A stable isotope aridity index for terrestrial environments. Proc. Natl. Acad. Sci. U.S.A. 103, 11201-11205. doi: 10.1073/pnas.0604719103

Lindeman, R. L. (1942). The trophic-dynamic aspect of ecology. Ecology 23, 399-417. doi: 10.2307/1930126

Luz, B., Cormie, A. B., and Schwarcz, H. P. (1990). Oxygen isotope variations in phosphate of deer bones. Geochim. Cosmochim. Acta 54, 1723-1728. doi: 10.1016/0016-7037(90)90403-8

Luz, B., and Kolodny, Y. (1985). Oxygen isotope variations in phosphate of biogenic apatites, IV. Mammal teeth and bones. Earth Planet. Sci. Lett. 75, 29-36. doi: 10.1016/0012-821X(85)90047-0

Luz, B., Kolodny, Y., and Horowitz, M. (1984). Fractionation of oxygen isotopes between mammalian bone-phosphate and environmental drinking water. Geochim. Cosmochim. Acta 48, 1689-1693. doi: 10.1016/0016-7037(84)90338-7

Marshall, J. D., Brooks, J. R., and Lajtha, K. (2007). "Sources in variation in the stable isotopic composition of plants," in Stable Isotopes in Ecology and Environmental Science, eds R. H. Michener and K. Lajtha (Malden, MA: Blackwell Publishing Ltd.), 22-60.

Martínez del Rio, C., Wolf, N., Carleton, S. A., and Gannes, L. Z. (2009). Isotopic ecology ten years after a call for more laboratory experiments. Biol. Rev. 84, 91-111. doi: 10.1111/j.1469-185X.2008.00064.x

McCluney, K. E., and Sabo, J. L. (2010). Tracing water sources of terrestrial animal populations with stable isotopes: laboratory tests with crickets and spiders. PLOS ONE 5:e15696. doi: 10.1371/journal.pone.0015696

McCutchan, J. H., Lewis, W. M., Kendall, C., and McGrath, C. C. (2003). Variation in trophic shift for stable isotope ratios of carbon, nitrogen, and sulfur. Oikos 102, 378-390. doi: 10.1034/j.1600-0706.2003.12098.x

McKechnie, A. E., Wolf, B. O., and Martínez del Rio, C. (2004). Deuterium stable isotope ratios as tracers of water resource use: an experimental test with rock doves. Oecologia 140, 191-200. doi: 10.1007/s00442-004-1564-9

Meehan, T. D., Rosenfield, R. N., Atudorei, V. N., Bielefeldt, J., Rosenfield, L. J., Stewart, A. C., et al. (2003). Variation in hydrogen stable-isotope ratios between adult and nestling cooper's hawks. Condor 105, 567-572. doi: 10.1650/7283

Meier-Augenstein, W. (2011). Stable Isotope Forensics: An Introduction to the Forensic Application of Stable Isotope Analysis. New York, NY: John Wiley \& Sons.

Meier-Augenstein, W., Chartrand, M. M. G., Kemp, H. F., and StJean, G. (2011). An inter-laboratory comparative study into sample preparation for both reproducible and repeatable forensic ${ }^{2} \mathrm{H}$ isotope analysis of human hair by continuous flow isotope ratio mass spectrometry. Rapid Commun. Mass Spectrom. 25, 3331-3338. doi: 10.1002/ rcm. 5235

Meier-Augenstein, W., Hobson, K. A., and Wassenaar, L. I. (2013). Critique: measuring hydrogen stable isotope abundance of proteins to infer origins of wildlife, food and people. Bioanalysis 5, 751-767. doi: 10.4155/bio.13.36

Michener, R., and Lajtha, K. (eds.). (2007). Stable Isotopes in Ecology and Environmental Science, 2nd Edn. Oxford: Blackwell Scientific.
Moritz, G. L., Fourie, N., Yeakel, J. D., Phillips-Conroy, J. E., Jolly, C. J., Koch, P. L., et al. (2012). Baboons, water, and the ecology of oxygen stable isotopes in an arid hybrid zone. Physiol. Biochem. Zool. Ecol. Evol. Approaches 85, 421-430. doi: $10.1086 / 667533$

Myers, D. J., Whitledge, G. W., and Whiles, M. R. (2012). Evaluation of $\delta$ D and $\delta^{18} \mathrm{O}$ as natural markers of invertebrate source environment and dispersal in the middle Mississippi River-floodplain ecosystem. River Res. Appl. 28, 135-142. doi: 10.1002/rra.1444

Nelson, S. V. (2013). Chimpanzee fauna isotopes provide new interpretations of fossil ape and hominin ecologies. Proc. R. Soc. Lond. B Biol. Sci. 280:20132324. doi: $10.1098 /$ rspb.2013.2324

Newsome, S. D., Martínez del Rio, C., Bearhop, S., and Phillips, D. L. (2007). A niche for isotopic ecology. Front. Ecol. Environ. 5, 429-436. doi: $10.1890 / 060150.1$

Newsome, S. D., Wolf, N., Peters, J., and Fogel, M. L. (2014). Amino acid $\delta^{13} \mathrm{C}$ analysis shows flexibility in the routing of dietary protein and lipids to the tissue of an omnivore. Integr. Comp. Biol. 54, 890-902. doi: 10.1093/icb/icu106

Newsome, S. D., Yeakel, J. D., Wheatley, P. V., and Tinker, M. T. (2012). Tools for quantifying isotopic niche space and dietary variation at the individual and population level. J. Mammal. 93, 329-341. doi: 10.1644/11-MAMM-S-187.1

Nielson, K. E., and Bowen, G. J. (2010). Hydrogen and oxygen in brine shrimp chitin reflect environmental water and dietary isotopic composition. Geochim. Cosmochim. Acta 74, 1812-1822. doi: 10.1016/j.gca.2009.12.025

O'Brien, D. M., and Wooller, M. J. (2007). Tracking human travel using stable oxygen and hydrogen isotope analyses of hair and urine. Rapid Commun. Mass Spectrom. 21, 2422-2430. doi: 10.1002/rcm.3108

Ofukany, A. F. A., Wassenaar, L. I., Bond, A. L., and Hobson, K. A. (2014). Defining fish community structure in Lake Winnipeg using stable isotopes $\left(\delta^{13} \mathrm{C}, \delta^{15} \mathrm{~N}\right.$, $\left.\delta^{34} \mathrm{~S}\right)$ : implications for monitoring ecological responses and trophodynamics of mercury and other trace elements. Sci. Total Environ. 497-498, 239-249. doi: 10.1016/j.scitotenv.2014.07.125

O’Grady, S. P., Valenzuela, L. O., Remien, C. H., Enright, L. E., Jorgensen, M. J., Kaplan, J. R., et al. (2012). Hydrogen and oxygen isotope ratios in body water and hair: modeling isotope dynamics in nonhuman primates. Am. J. Primatol. 74, 651-660. doi: 10.1002/ajp.22019

O'Grady, S. P., Wende, A. R., Remien, C. H., Valenzuela, L. O., Enright, L. E., Chesson, L. A., et al. (2010). Aberrant water homeostasis detected by stable isotope analysis. PLoS ONE 5:e11699. doi: 10.1371/journal.pone.0011699

Pecquerie, L., Nisbet, R. M., Fablet, R., Lorrain, A., and Kooijman, S. A. L. M. (2010). The impact of metabolism on stable isotope dynamics: a theoretical framework. Philos. Trans. R. Soc. Lond. B Biol. Sci. 365, 3455-3468. doi: 10.1098/rstb.2010.0097

Peters, J. M., Wolf, N., Stricker, C. A., Collier, T. R., and Martínez del Rio, C. (2012). Effects of trophic level and metamorphosis on discrimination of hydrogen isotopes in a plant-herbivore system. PLOS ONE 7:e32744. doi: 10.1371/journal.pone.0032744

Peterson, B. J., and Fry, B. (1987). Stable isotopes in ecosystem studies. Annu. Rev. Ecol. Syst. 18, 293-320. doi: 10.1146/annurev.es.18.110187.001453

Phillips, D. L., Inger, R., Bearhop, S., Jackson, A. L., Moore, J. W., Parnell, A. C., et al. (2014). Best practices for use of stable isotope mixing models in food-web studies. Can. J. Zool. 92, 823-835. doi: 10.1139/cjz-2014-0127

Pietsch, S. J., Hobson, K. A., Wassenaar, L. I., and Tütken, T. (2011). Tracking cats: problems with placing feline carnivores on $\delta^{18} \mathrm{O}, \delta \mathrm{D}$ isoscapes. PLoS ONE 6:e24601. doi: 10.1371/journal.pone.0024601

Podlesak, D. W., Bowen, G. J., O'Grady, S., Cerling, T. E., and Ehleringer, J. R. (2012). $\delta^{2} \mathrm{H}$ and $\delta^{18} \mathrm{O}$ of human body water: a GIS model to distinguish residents from non-residents in the contiguous USA. Isotopes Environ. Health Stud. 48, 259-279. doi: 10.1080/10256016.2012.644283

Podlesak, D. W., Torregrossa, A.-M., Ehleringer, J. R., Dearing, M. D., Passey, B. H., and Cerling, T. E. (2008). Turnover of oxygen and hydrogen isotopes in the body water, $\mathrm{CO}_{2}$, hair, and enamel of a small mammal. Geochim. Cosmochim. Acta 72, 19-35. doi: 10.1016/j.gca.2007.10.003

Polis, G. A., Anderson, W. B., and Holt, R. D. (1997). Toward an integration of landscape and food web ecology: the dynamics of spatially subsidized food webs. Annu. Rev. Ecol. Syst. 28, 289-316. doi: 10.1146/annurev.ecolsys. 28.1.289

Polis, G. A., and Hurd, S. D. (1996). Linking marine and terrestrial food webs: allochthonous input from the ocean supports high secondary productivity 
on small islands and coastal land communities. Am. Nat. 147, 396-423. doi: $10.1086 / 285858$

Polis, G. A., and Strong, D. R. (1996). Food web complexity and community dynamics. Am. Nat. 147, 813-846. doi: 10.1086/285880

Post, D. M. (2002). Using stable isotopes to estimate trophic position: models, methods, and assumptions. Ecology 83, 703-718. doi: 10.1890/00129658(2002)083[0703:USITET]2.0.CO;2

Post, D. M., Layman, C. A., Arrington, D. A., Takimoto, G., Quattrochi, J., and Montaña, C. G. (2007). Getting to the fat of the matter: models, methods and assumptions for dealing with lipids in stable isotope analyses. Oecologia 152, 179-189. doi: 10.1007/s00442-006-0630-x

Qi, H., and Coplen, T. B. (2011). Investigation of preparation techniques for $\delta^{2} \mathrm{H}$ analysis of keratin materials and a proposed analytical protocol. Rapid Commun. Mass Spectrom. 25, 2209-2222. doi: 10.1002/rcm.5095

Qi, H., Coplen, T. B., and Wassenaar, L. I. (2011). Improved online $\delta^{18} \mathrm{O}$ measurements of nitrogen- and sulfur-bearing organic materials and a proposed analytical protocol. Rapid Commun. Mass Spectrom. 25, 2049-2058. doi: $10.1002 / \mathrm{rcm} .5088$

Reich, K. J., Bjorndal, K. A., and Martínez del Rio, C. (2008). Effects of growth and tissue type on the kinetics of ${ }^{13} \mathrm{C}$ and ${ }^{15} \mathrm{~N}$ incorporation in a rapidly growing ectotherm. Oecologia 155, 651-663. doi: 10.1007/s00442-007-0949-y

Reynard, L. M., and Hedges, R. E. M. (2008). Stable hydrogen isotopes of bone collagen in palaeodietary and palaeoenvironmental reconstruction. J. Archaeol. Sci. 35, 1934-1942. doi: 10.1016/j.jas.2007.12.004

Richardson, J. S., Zhang, Y., and Marczak, L. B. (2010). Resource subsidies across the land-freshwater interface and responses in recipient communities. River Res. Appl. 26, 55-66. doi: 10.1002/rra.1283

Roach, K. A., and Winemiller, K. O. (2015). Hydrologic regime and turbidity influence entrance of terrestrial material into river food webs. Can. J. Fish. Aquat. Sci. 72, 1099-1112. doi: 10.1139/cjfas-2014-0459

Robbins, C. T., Felicetti, L. A., and Sponheimer, M. (2005). The effect of dietary protein quality on nitrogen isotope discrimination in mammals and birds. Oecologia 144, 534-540. doi: 10.1007/s00442-005-0021-8

Roden, J. S., and Ehleringer, J. R. (1999). Observations of hydrogen and oxygen isotopes in leaf water confirm the Craig-Gordon model under wide-ranging environmental conditions. Plant Physiol. 120, 1165-1174. doi: 10.1104/pp.120.4.1165

Roden, J. S., Lin, G., and Ehleringer, J. R. (2000). A mechanistic model for interpretation of hydrogen and oxygen isotope ratios in tree-ring cellulose. Geochim. Cosmochim. Acta 64, 21-35. doi: 10.1016/S0016-7037(99)00195-7

Rosenfeld, J. S., and Roff, J. C. (1992). Examination of the carbon base in southern Ontario streams using stable isotopes. J. North Am. Benthol. Soc. 11, 1-10. doi: $10.2307 / 1467877$

Roth, J. D., and Hobson, K. A. (2000). Stable carbon and nitrogen isotopic fractionation between diet and tissue of captive red fox: implications for dietary reconstruction. Can. J. Zool. 78, 848-852. doi: 10.1139/z00-008

Rundel, P. W., Ehleringer, J. R., and Nagy, K. A. (eds.). (1989). Stable Isotopes in Ecological Research. New York, NY: Springer.

Sachse, D., Billault, I., Bowen, G. J., Chikaraishi, Y., Dawson, T. E., Feakins, S. J., et al. (2012). Molecular paleohydrology: interpreting the hydrogen-isotopic composition of lipid biomarkers from photosynthesizing organisms. Annu. Rev. Earth Planet. Sci. 40, 221-249. doi: 10.1146/annurev-earth-042711-105535

Schilder, J., Tellenbach, C., Möst, M., Spaak, P., van Hardenbroek, M., Wooller, M. J., et al. (2015). The stable isotopic composition of Daphnia ephippia reflects changes in $\delta^{13} \mathrm{C}$ and $\delta^{18} \mathrm{O}$ values of food and water. Biogeosciences 12, 3819-3830. doi: 10.5194/bg-12-3819-2015

Schindler, D. E., and Lubetkin, S. C. (2004). "Using stable isotopes to quantify material transport in food webs," in Food Webs at the Landscape Level, eds G. A. Polis, M. E. Power, and G. R. Huxley (Chicago: University of Chicago Press), 25-42.

Schoeller, D. A. (1999). Recent advances from application of doubly labeled water to measurement of human energy expenditure. J. Nutr. 129, 1765-1768.

Sessions, A. L., Burgoyne, T. W., Schimmelmann, A., and Hayes, J. M. (1999). Fractionation of hydrogen isotopes in lipid biosynthesis. Org. Geochem. 30, 1193-1200. doi: 10.1016/S0146-6380(99)00094-7

Sharp, Z. D., Atudorei, V., Panarello, H. O., Fernández, J., and Douthitt, C. (2003). Hydrogen isotope systematics of hair: archeological and forensic applications. J. Archaeol. Sci. 30, 1709-1716. doi: 10.1016/S0305-4403(03)00071-2
Singer, G. A., Panzenböck, M., Weigelhofer, G., Marchesani, C., Waringer, J., Wanek, W., et al. (2005). Flow history explains temporal and spatial variation of carbon fractionation in stream periphyton. Limnol. Oceanogr. 50, 706-712. doi: 10.4319/lo.2005.50.2.0706

Smith, A. D., Donohue, K., and Dufty, A. M. (2008). Intrafeather and intraindividual variation in the stable-hydrogen isotope $(\delta \mathrm{D})$ content of raptor feathers. Condor 110, 500-506. doi: 10.1525/cond.2008.8515

Solomon, C. T., Carpenter, S. R., Clayton, M. K., Cole, J. J., Coloso, J. J., Pace, M. L., et al. (2011). Terrestrial, benthic, and pelagic resource use in lakes: results from a three-isotope Bayesian mixing model. Ecology 92, 1115-1125. doi: 10.1890/10-1185.1

Solomon, C. T., Cole, J. J., Doucett, R. R., Pace, M. L., Preston, N. D., Smith, L. E., et al. (2009). The influence of environmental water on the hydrogen stable isotope ratio in aquatic consumers. Oecologia 161, 313-324. doi: 10.1007/s00442-009-1370-5

Soto, D. X., Gacia, E., and Catalan, J. (2013a). Freshwater food web studies: a plea for multiple tracer approach. Limnetica 32, 97-106. Available online at: http://www.limnetica.com/Limnetica/Limne32/L32a097_Multiple_tracers_ of_freshwater_food_webs.pdf

Soto, D. X., Hobson, K. A., and Wassenaar, L. I. (2013b). The influence of metabolic effects on stable hydrogen isotopes in tissues of aquatic organisms. Isotopes Environ. Health Stud. 49, 305-311. doi: 10.1080/10256016.2013.820727

Soto, D. X., Wassenaar, L. I., and Hobson, K. A. (2013c). Stable hydrogen and oxygen isotopes in aquatic food webs are tracers of diet and provenance. Funct. Ecol. 27, 535-543. doi: 10.1111/1365-2435.12054

Soto, D. X., Wassenaar, L. I., Hobson, K. A., and Catalan, J. (2011). Effects of size and diet on stable hydrogen isotope values $(\delta \mathrm{D})$ in fish: implications for tracing origins of individuals and their food sources. Can. J. Fish. Aquat. Sci. 68, 2011-2019. doi: 10.1139/f2011-112

Stapp, P., Polls, G. A., and Sánchez Piñero, F. (1999). Stable isotopes reveal strong marine and El Niño effects on island food webs. Nature 401, 467-469.

Stenroth, K., Polvi, L. E., Fältström, E., and Jonsson, M. (2015). Land-use effects on terrestrial consumers through changed size structure of aquatic insects. Freshw. Biol. 60, 136-149. doi: 10.1111/fwb.12476

Sternberg, L. O., DeNiro, M. J., and Johnson, H. B. (1984). Isotope ratios of cellulose from plants having different photosynthetic pathways. Plant Physiol. 74, 557-561. doi: 10.1104/pp.74.3.557

Storm-Suke, A., Norris, D. R., Wassenaar, L. I., Chin, E., and Nol, E. (2012). Factors influencing the turnover and net isotopic discrimination of hydrogen isotopes in proteinaceous tissue: experimental results using Japanese quail. Physiol. Biochem. Zool. 85, 376-384. doi: 10.1086/666476

Tatner, P. (1988). A model of the natural abundance of oxygen-18 and deuterium in the body water of animals. J. Theor. Biol. 133, 267-280. doi: 10.1016/S00225193(88)80321-7

Thompson, A. H., Chesson, L. A., Podlesak, D. W., Bowen, G. J., Cerling, T. E., and Ehleringer, J. R. (2010). Stable isotope analysis of modern human hair collected from Asia (China, India, Mongolia, and Pakistan). Am. J. Phys. Anthropol. 141, 440-451. doi: 10.1002/ajpa.21162

Tonra, C. M., Both, C., and Marra, P. P. (2015). Incorporating site and year-specific deuterium ratios $\left(\delta^{2} \mathrm{H}\right)$ from precipitation into geographic assignments of a migratory bird. J. Avian Biol. 46, 266-274. doi: 10.1111/jav.00553

Topalov, K., Schimmelmann, A., David Polly, P., Sauer, P. E., and Lowry, M. (2013). Environmental, trophic, and ecological factors influencing bone collagen $\delta^{2}$ H. Geochim. Cosmochim. Acta 111, 88-104. doi: 10.1016/j.gca.2012. 11.017

Trudeau, V., and Rasmussen, J. B. (2003). The effect of water velocity on stable carbon and nitrogen isotope signatures of periphyton. Limnol. Oceanogr. 48, 2194-2199. doi: 10.4319/lo.2003.48.6.2194

Trueman, C. N., McGill, R. A. R., and Guyard, P. H. (2005). The effect of growth rate on tissue-diet isotopic spacing in rapidly growing animals. An experimental study with Atlantic salmon (Salmo salar). Rapid Commun. Mass Spectrom. 19, 3239-3247. doi: 10.1002/rcm.2199

Tuross, N., Warinner, C., Kirsanow, K., and Kester, C. (2008). Organic oxygen and hydrogen isotopes in a porcine controlled dietary study. Rapid Commun. Mass Spectrom. 22, 1741-1745. doi: 10.1002/rcm.3556

Vanderklift, M. A., and Ponsard, S. (2003). Sources of variation in consumerdiet $\delta^{15} \mathrm{~N}$ enrichment: a meta-analysis. Oecologia 136, 169-182. doi: $10.1007 / \mathrm{s} 00442-003-1270-\mathrm{z}$ 
Vander Zanden, H. B., Bjorndal, K. A., Inglett, P. W., and Bolten, A. B. (2012). Marine-derived nutrients from green turtle nests subsidize terrestrial beach ecosystems. Biotropica 44, 294-301. doi: 10.1111/j.1744-7429.2011.00827.x

Vander Zanden, H. B., Wunder, M. B., Hobson, K. A., Van Wilgenburg, S. L., Wassenaar, L. I., Welker, J. M., et al. (2014). Contrasting assignment of migratory organisms to geographic origins using long-term versus year-specific precipitation isotope maps. Methods Ecol. Evol. 5, 891-900. doi: 10.1111/2041210X.12229

Vander Zanden, H. B., Wunder, M. B., Hobson, K. A., Van Wilgenburg, S. L., Wassenaar, L. I., Welker, J. M., et al. (2015a). Space-time tradeoffs in the development of precipitation-based isoscape models for determining migratory origin. J. Avian Biol. 46, 658-657. doi: 10.1111/jav.00656

Vander Zanden, M. J., Clayton, M. K., Moody, E. K., Solomon, C. T., and Weidel, B. C. (2015b). Stable isotope turnover and half-life in animal tissues: a literature synthesis. PLoS ONE 10:e0116182. doi: 10.1371/journal.pone.0116182

Voigt, C. C., Lehmann, D., and Greif, S. (2015). Stable isotope ratios of hydrogen separate mammals of aquatic and terrestrial food webs. Methods Ecol. Evol. 6, 1332-1340. doi: 10.1111/2041-210X.12414

Walker, C. D., and Brunel, J.-P. (1990). Examining evapotranspiration in a semiarid region using stable isotopes of hydrogen and oxygen. J. Hydrol. 118, 55-75. doi: 10.1016/0022-1694(90)90250-2

Wang, Y. V., O’Brien, D. M., Jenson, J., Francis, D., and Wooller, M. J. (2009). The influence of diet and water on the stable oxygen and hydrogen isotope composition of Chironomidae (Diptera) with paleoecological implications. Oecologia 160, 225-233. doi: 10.1007/s00442-009-1303-3

Wassenaar, L. I., and Hobson, K. A. (2000). Improved method for determining the stable-hydrogen isotopic composition $(\delta \mathrm{D})$ of complex organic materials of environmental interest. Environ. Sci. Technol. 34, 2354-2360. doi: $10.1021 / \mathrm{es} 990804 \mathrm{i}$

Wassenaar, L. I., and Hobson, K. A. (2003). Comparative equilibration and online technique for determination of non-exchangeable hydrogen of keratins for use in animal migration studies. Isotopes Environ. Health Stud. 39, 211-217. doi: $10.1080 / 1025601031000096781$

Wassenaar, L. I., and Hobson, K. A. (2006). Stable-hydrogen isotope heterogeneity in keratinous materials: mass spectrometry and migratory wildlife tissue subsampling strategies. Rapid Commun. Mass Spectrom. 20, 2505-2510. doi: $10.1002 / \mathrm{rcm} .2626$

Wassenaar, L. I., Hobson, K. A., and Sisti, L. (2015). An online temperaturecontrolled vacuum-equilibration preparation system for the measurement of $\delta^{2} \mathrm{H}$ values of non-exchangeable- $\mathrm{H}$ and of $\delta^{18} \mathrm{O}$ values in organic materials by isotope-ratio mass spectrometry. Rapid Commun. Mass Spectrom. 29, 397-407. doi: $10.1002 / \mathrm{rcm} .7118$

Wilkinson, G. M., Carpenter, S. R., Cole, J. J., Pace, M. L., and Yang, C. (2013a). Terrestrial support of pelagic consumers: patterns and variability revealed by a multilake study. Freshw. Biol. 58, 2037-2049. doi: 10.1111/fwb.12189

Wilkinson, G. M., Cole, J. J., and Pace, M. L. (2015). Deuterium as a food source tracer: sensitivity to environmental water, lipid content, and hydrogen exchange. Limnol. Oceanogr. Methods 13, 213-223. doi: 10.1002/lom3. 10019

Wilkinson, G. M., Pace, M. L., and Cole, J. J. (2013b). Terrestrial dominance of organic matter in north temperate lakes. Glob. Biogeochem. Cycles 27, 43-51. doi: $10.1029 / 2012$ GB004453

Wolf, B. O., and Martínez del Rio, C. (2000). Use of saguaro fruit by whitewinged doves: isotopic evidence of a tight ecological association. Oecologia 124, 536-543. doi: 10.1007/s004420000406

Wolf, B. O., Martínez del Rio, C., and Babson, J. (2002). Stable isotopes reveal that saguaro fruit provides different resources to two desert dove species. Ecology 83 , 1286-1293. doi: 10.1890/0012-9658(2002)083[1286:SIRTSF]2.0.CO;2

Wolf, N., Bowen, G. J., and Martínez del Rio, C. (2011). The influence of drinking water on the $\delta \mathrm{D}$ and $\delta^{18} \mathrm{O}$ values of house sparrow plasma, blood and feathers. J. Exp. Biol. 214, 98-103. doi: 10.1242/jeb.050211

Wolf, N., Newsome, S. D., Fogel, M. L., and Martínez del Rio, C. (2012). An experimental exploration of the incorporation of hydrogen isotopes from dietary sources into avian tissues. J. Exp. Biol. 215, 1915-1922. doi: $10.1242 /$ jeb.065219

Wolf, N., Newsome, S. D., Peters, J., and Fogel, M. L. (2015). Variability in the routing of dietary proteins and lipids to consumer tissues influences tissue-specific isotopic discrimination. Rapid Commun. Mass Spectrom. 29, 1448-1456. doi: 10.1002/rcm.7239

Wunder, M. B., Jehl, J. R. Jr., and Stricker, C. A. (2012). The early bird gets the shrimp: confronting assumptions of isotopic equilibrium and homogeneity in a wild bird population. J. Anim. Ecol. 81, 1223-1232. doi: 10.1111/j.13652656.2012.01998.x

Yakir, D., and Deniro, M. J. (1990). Oxygen and hydrogen isotope fractionation during cellulose metabolism in Lemna gibba L. Plant Physiol. 93, 325-332. doi: 10.1104/pp.93.1.325

Zazzo, A., Cerling, T. E., Ehleringer, J. R., Moloney, A. P., Monahan, F. J., and Schmidt, O. (2015). Isotopic composition of sheep wool records seasonality of climate and diet. Rapid Commun. Mass Spectrom. 29, 1357-1369. doi: $10.1002 / \mathrm{rcm} .7228$

Zhang, X., Gillespie, A. L., and Sessions, A. L. (2009). Large D/H variations in bacterial lipids reflect central metabolic pathways. Proc. Natl. Acad. Sci. U.S.A. 106, 12580-12586. doi: 10.1073/pnas.0903030106

Conflict of Interest Statement: The authors declare that the research was conducted in the absence of any commercial or financial relationships that could be construed as a potential conflict of interest.

Copyright (๑) 2016 Vander Zanden, Soto, Bowen and Hobson. This is an open-access article distributed under the terms of the Creative Commons Attribution License (CC $B Y)$. The use, distribution or reproduction in other forums is permitted, provided the original author(s) or licensor are credited and that the original publication in this journal is cited, in accordance with accepted academic practice. No use, distribution or reproduction is permitted which does not comply with these terms. 